\title{
Effects of aging on organic aerosol from open biomass burning smoke in aircraft and laboratory studies
}

\author{
M. J. Cubison ${ }^{1,2}$, A. M. Ortega ${ }^{1,3}$, P. L. Hayes ${ }^{1,2}$, D. K. Farmer ${ }^{1,2}$, D. Day ${ }^{1,2}$, M. J. Lechner ${ }^{1}$, W. H. Brune , E. Apel $^{5}$, \\ G. S. Diskin ${ }^{6}$, J. A. Fisher ${ }^{7}$, H. E. Fuelberg ${ }^{8}$, A. Hecobian ${ }^{9}$, D. J. Knapp ${ }^{5}$, T. Mikoviny ${ }^{10}$, D. Riemer ${ }^{11}$, G. W. Sachse ${ }^{12}$, \\ W. Sessions ${ }^{8}$, R. J. Weber ${ }^{9}$, A. J. Weinheimer ${ }^{5}$, A. Wisthaler ${ }^{10}$, and J. L. Jimenez ${ }^{1,2}$ \\ ${ }^{1}$ Cooperative Institute for Research in Environmental Sciences, University of Colorado, Boulder, Colorado, USA \\ ${ }^{2}$ Department of Chemistry and Biochemistry, University of Colorado, Boulder, Colorado, USA \\ ${ }^{3}$ Department of Atmospheric and Oceanic Science, University of Colorado, Boulder, Colorado, USA \\ ${ }^{4}$ Department of Meteorology, Pennsylvania State University, University Park, Pennsylvania, USA \\ ${ }^{5}$ National Center for Atmospheric Research, Boulder, Colorado, USA \\ ${ }^{6}$ NASA Langley Research Center, Hampton, Virginia, USA \\ ${ }^{7}$ Department of Earth and Planetary Sciences, Harvard University, Cambridge, Massachusetts, USA \\ ${ }^{8}$ Department of Earth, Ocean, and Atmospheric Science, Florida State University, Tallahassee, Florida, USA \\ ${ }^{9}$ School of Earth and Atmospheric Sciences, Georgia Institute of Technology, Atlanta, Georgia, USA \\ ${ }^{10}$ Institut für Ionenphysik \& Angewandte Physik, Universität Innsbruck, Innsbruck, Austria \\ ${ }^{11}$ Rosenstiel School of Marine and Atmospheric Chemistry, University of Miami, Miami, Florida, USA \\ ${ }^{12}$ National Institute of Aerospace, Hampton, Virginia, USA
}

Received: 19 March 2011 - Published in Atmos. Chem. Phys. Discuss.: 19 April 2011

Revised: 30 October 2011 - Accepted: 18 November 2011 - Published: 5 December 2011

\begin{abstract}
Biomass burning (BB) is a large source of primary and secondary organic aerosols (POA and SOA). This study addresses the physical and chemical evolution of BB organic aerosols. Firstly, the evolution and lifetime of BB POA and SOA signatures observed with the Aerodyne Aerosol Mass Spectrometer are investigated, focusing on measurements at high-latitudes acquired during the 2008 NASA ARCTAS mission, in comparison to data from other field studies and from laboratory aging experiments. The parameter $f_{60}$, the ratio of the integrated signal at $m / z 60$ to the total signal in the organic component mass spectrum, is used as a marker to study the rate of oxidation and fate of the $\mathrm{BB}$ POA. A background level of $f_{60} \sim 0.3 \% \pm 0.06 \%$ for SOAdominated ambient OA is shown to be an appropriate background level for this tracer. Using also $f_{44}$ as a tracer for SOA and aged POA and a surrogate of organic O:C, a novel graphical method is presented to characterise the aging of BB plumes. Similar trends of decreasing $f_{60}$ and increasing $f_{44}$ with aging are observed in most field and lab studies. At least some very aged BB plumes retain a clear
\end{abstract}

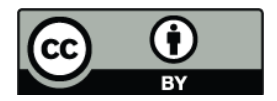

Correspondence to: J. L. Jimenez (jose.jimenez@colorado.edu) $f_{60}$ signature. A statistically significant difference in $f_{60}$ between highly-oxygenated $\mathrm{OA}$ of $\mathrm{BB}$ and non-BB origin is observed using this tracer, consistent with a substantial contribution of BBOA to the springtime Arctic aerosol burden in 2008. Secondly, a summary is presented of results on the net enhancement of OA with aging of BB plumes, which shows large variability. The estimates of net OA gain range from $\Delta \mathrm{OA} / \Delta \mathrm{CO}$ (mass) $=-0.01$ to $\sim 0.05$, with a mean $\triangle \mathrm{OA} / \mathrm{POA} \sim 19 \%$. With these ratios and global inventories of $\mathrm{BB} \mathrm{CO}$ and $\mathrm{POA}$ a global net $\mathrm{OA}$ source due to aging of $\mathrm{BB}$ plumes of $\sim 8 \pm 7 \mathrm{Tg} \mathrm{OA} \mathrm{yr}^{-1}$ is estimated, of the order of $5 \%$ of recent total OA source estimates. Further field data following BB plume advection should be a focus of future research in order to better constrain this potentially important contribution to the OA burden.

\section{Introduction}

Organic aerosols (OA) are an important subset of the submicron aerosol population worldwide (Murphy et al., 2006; Zhang et al., 2007). Despite intensive research, the impacts of OA on climate, human health and visibility are poorly constrained and further understanding of their sources,

Published by Copernicus Publications on behalf of the European Geosciences Union. 
physical and chemical properties and atmospheric processing is needed. Biomass-burning (BB) aerosols are composed of a large fraction of organic matter (BBOA), and are an important global contributor to the global OA load due to their emissions of primary OA (POA) (e.g. Bond et al., 2004; de Gouw and Jimenez, 2009). Recent studies have demonstrated the semi-volatile nature of BB POA, which can lead to substantial evaporation upon dilution of BB plumes (Robinson et al., 2007; Huffman et al., 2009a, b). BB emissions have been recently confirmed as a potentially large source of secondary OA (SOA), at least some of which may be formed from reactions of evaporated POA (Grieshop et al., 2009a, b). The net enhancement of the OA mass after evaporation and SOA formation in BB plumes has only recently been quantified in several recent field studies using fast instrumentation, and has sometimes been substantial (e.g. Yokelson et al., 2009) and other times negligible (Capes et al., 2008; Hecobian et al., 2011). Results from laboratory studies of the aging of open BB emissions mirror these findings, demonstrating a wide range of measured net OA production depending on, among other factors, the fuel and burning conditions (Hennigan et al., 2011; Ortega et al., 2010). Further understanding of the magnitude and extent of both the primary and secondary components of BBOA is required to fully assess the impacts from local to global geographical scales.

The chemical aging of BB POA and formation of oxygenated organic aerosol (OOA) due to photochemistry has been observed in both chamber (Grieshop et al., 2009b; Jimenez et al., 2009) and field studies (DeCarlo et al., 2010). Following from the study of Alfarra et al. (2004), the changing oxidation of OA under the influence of photochemical processes has been extensively described in the literature using the parameter $f_{44}$, the fraction of the OA mass spectrum signal at $m / z, 44$ in Aerodyne Aerosol Mass Spectrometer (AMS; Canagaratna et al., 2007) data. (Additional ratios for other $m / z \mathrm{i}, f_{i}$, are similarly defined for other integer mass signals.) Higher $f_{44}$ values represent higher fractions of OOA and/or more-oxidised OOA, which has been shown to be a surrogate for SOA under most conditions (Volkamer et al., 2006; Jimenez et al., 2009). Some OOA can be formed via heterogeneous aging of POA, although this process is slower than SOA formation (DeCarlo et al., 2008; Jimenez et al., 2009; George and Abbatt, 2010). $f_{44}$ has also been shown to be linearly correlated with the elemental oxygen/carbon ratio (O:C) of ambient OA (Aiken et al., 2007). Higher $f_{44}$ and O:C are also associated with increasing hygroscopicity and cloud nucleation ability of OA particles (Jimenez et al., 2009; Duplissy et al., 2011), with increasing carboxylic acid content (Takegawa et al., 2007; Duplissy et al., 2011; Hawkins and Russell, 2010), and also with decreasing volatility of the OOA, giving rise to the lumped OOA subtypes semi-volatile-OOA (SV-OOA) and low-volatility-OOA (LV-OOA) (Huffman et al., 2009; Jimenez et al., 2009; Cappa and Jimenez, 2010). All of the previously reported systems in the literature have shown chemical transformations that push the measured OA toward LV-OOA, independent of the original OA source (Jimenez et al., 2009; $\mathrm{Ng}$ et al., 2010), with an endpoint in $f_{44}$ space at $\sim 0.27$. Beyond this point, it has been suggested that further chemical transformations are either slow or result in OA loss through volatilisation (Jimenez et al., 2009; Kessler et al., 2010; Kroll et al., 2011).

Estimates of $\mathrm{BB}$ aerosol concentrations from field data (containing $\mathrm{OA}$ also from various non-BB sources) have been traditionally based on tracer species. The two most commonly used tracers are potassium and levoglucosan. Potassium (K) is not reactive, but Zhang et al. (2010) report poor correlation between $\mathrm{K}$ and fire counts in the Southeast US, which they attribute to the influence of other K sources such as soil dust, sea salt, vegetation and meat cooking. A high $\mathrm{K}$ background due to non-BB sources was also reported by Aiken et al. (2010) for Mexico City. Levoglucosan is an organic molecule formed in the pyrolysis of cellulose that is emitted in substantial amounts by BB sources (Simoneit et al., 1999), but it has been shown in recent studies to degrade during photochemical aging (Hennigan et al., 2010).

Recently BBOA has also been identified in a range of environments through deconvolution of OA mass-spectra from the AMS (e.g. Alfarra et al., 2007; Jimenez et al., 2009; Aiken et al., 2009, 2010). Fresh BBOA observed with the AMS has been shown to correlate well with well-known gasphase markers of BB activity such as acetonitrile, in addition to a number of other metrics for BB (Aiken et al., 2010). BBOA identified with the AMS was also recently shown to be strongly correlated $(R=0.89)$ with BBOA extracted from factor analysis of Fourier Transform Infrared Spectroscopy (FTIR) analysis of BB-influenced organic matter (OM) data (Hawkins and Russell, 2010, their Fig. 2). Key tracers of BBOA in AMS spectra are the enhanced signals at $\mathrm{m} / z 60$ and 73 from the ions $\mathrm{C}_{2} \mathrm{H}_{4} \mathrm{O}_{2}^{+}$and $\mathrm{C}_{3} \mathrm{H}_{5} \mathrm{O}_{2}^{+}$(Schneider et al., 2006; Alfarra et al., 2007). Levoglucosan and similar species (mannosan, galactosan) produce an enhanced signal at $m / z$ 60. For example, $f_{60}$ for levoglucosan is $13 \%$ (Schneider et al., 2006; Aiken et al., 2007). However the total signal at $m / z 60$ in BBOA is 3-10 times larger than would be expected from levoglucosan, mannosan, or galactosan, indicating that most of it arises from different molecules that fragment in a similar way as levoglucosan in the AMS (Aiken et al., 2009; Lee et al., 2010). As levoglucosan is a monomer arising from the pyrolysis of cellulose, it is possible that species such as dimers and trimers of similar molecules account for the rest of the signal at $m / z 60$ in BBOA. We define such species here as "levoglucosan-like" species.

In addition, it is known that signal at $m / z 60$ is also observed from carboxylic acids from SOA (DeCarlo et al., 2008; Docherty et al., 2008; Ulbrich et al., 2009a; Aiken et al., 2010) and fatty acids in cooking POA (Mohr et al., 2009), while motor vehicle exhaust produces very low levels of this tracer (Mohr et al., 2009). Typical gas-phase electron ionisation of carboxylic acids produces major ions at $m / z 60$ and 
73 (see NIST database, http://webbook.nist.gov/chemistry/) but, in the AMS, these acids produce ions mostly at $m / z 44$ due to thermal decomposition on the vapouriser, and only produce minor signals at $m / z 60$ and 73. In ambient observations at several locations, $f_{60}$ of $\sim 0.3 \%$ has been observed as a background level in air masses not impacted by active open biomass burning, as characterised by fire counts and other BB tracers such as acetonitrile (Docherty et al., 2008; DeCarlo et al., 2008; Aiken et al., 2009). This background level needs to be taken into account in any attempt to infer BBOA impact from ambient AMS observations of $f_{60}$.

The persistence of atmospheric markers is a required assumption for standard receptor model studies (Schauer et al., 1996), but recent studies have shown that organic molecular tracers can decay in the atmosphere due to photochemical processing (e.g. Robinson et al., 2006). Levoglucosan is known to oxidise in the atmosphere and the pathways and rate of its oxidation have been the subject of recent research (Hoffman et al., 2010; Kessler et al., 2010; Hennigan et al., 2010). These laboratory-based studies have estimated a range of lifetimes for levoglucosan under typical atmospheric conditions of $15 \mathrm{~h}$ to 10 days. However, the extent of levoglucosan or $f_{60}$ degradation after long aging times is difficult to assess from chamber measurements owing to wall effects and the finite measurement period. Differences in phase and morphology between laboratory and ambient particles may also result in differences between oxidation lifetimes. For example, previous studies showed that oleic acid survives in the atmosphere much longer than expected based on its pure-component reactivity (Ziemann, 2005), potentially due to being trapped on a solid or glassy phase (Katrib et al., 2005; Hung and Tang, 2010). Such glassy organic phases are thought to be common in the atmosphere (Virtanen et al., 2010; Vaden et al., 2011) and similar effects may play a role for levoglucosan and other levoglucosan-like species.

AMS $f_{60}$ has also been reported to decrease during photochemical processing of BBOA, due to both addition of SOA and evaporation/reaction of POA species. Huffman et al. (2009b) reported that $f_{60}$ showed a volatility slightly higher than the bulk primary BBOA for many different biomasses, so it is likely that evaporation plays a role in the evolution of this tracer. However, it remains unclear whether $f_{60}$ will persist sufficiently in aged BBOA to serve as a marker, especially for BBOA plumes advected on a continental or global scale where the transport times are multiple days.

In this study, the physical and chemical aging of BBOA were studied in the field and compared to laboratory results. The decay of the AMS $f_{60}$ marker of primary BBOA and the increase of the $f_{44}$ marker of secondary BBOA were investigated. Through comparison of BBOA-dominated measurements with those known to be free of BB influence, the chemical evolution of BBOA can be assessed. The net effect of BB plume aging on OA mass is also summarised, and a first global estimate of the net OA source is presented.

\section{Methods}

The OA measurements presented here have been obtained, unless stated otherwise, using the University of Colorado Aerodyne high-resolution time-of-flight mass spectrometer (HR-ToF-AMS, DeCarlo et al., 2006). The AMS vapouriser temperature was $600^{\circ} \mathrm{C}$ for all studies. All data were analysed in high-resolution (HR), but are mostly reported here at unit-mass-resolution (UMR) for simplicity. The AMS UMR signal at $\mathrm{m} / \mathrm{z} 60$ and the high-resolution $\mathrm{C}_{2} \mathrm{H}_{4} \mathrm{O}_{2}^{+}$AMS ion signal are tightly correlated for data from two ARCTAS flights (Fig. S1). This correlation spans three orders of magnitude and demonstrates the the negligible contribution of other ions in the ambient AMS spectrum to the unit mass integration at $m / z 60$, validating the application of the UMR ratio $f_{60}$ in use as a tracer. A similar analysis as to that presented in this work could also be conducted using $f_{73}$, which shows a well-correlated linear relationship with $f_{60}$ in the ARCTAS measurements. This slope is very similar slope than for BBOA data from the AMS database, and different from the higher slopes observed for most chamber SOA (Fig. S2). However, the aircraft signal at $m / z 73$ is somewhat lower and noisier than at $m / z 60$, so somewhat more restrictive constraints would be required on the signalto-noise ratios in order to draw similar conclusions.

While gas-phase $\mathrm{CO}_{2}$ also produces a signal at $m / z 44$, the effect of this interference in aerosol variables such as $f_{44}$ is minor for the AMS, and can be corrected for. The AMS samples particles more efficiently than gases by a factor of about $10^{7}$. Therefore the equivalent particle-phase signal from typical ambient concentrations of gas-phase $\mathrm{CO}_{2}(\sim 380 \mathrm{ppm})$ corresponds to an equivalent organic aerosol concentration of $\sim 40 \mathrm{ng} \mathrm{m}^{-3}$. This average is always subtracted from the reported OA concentrations using the fragmentation table approach of Allan et al. (2004). Therefore it is only increases above the background $\mathrm{CO}_{2}$ concentration that would produce a positive bias on the aerosol concentration and $f_{44}$. If only the average subtraction is used, and for typical gas-phase $\mathrm{CO}_{2}$ enhancements during ARCTAS of the order of $10 \mathrm{ppm}$ or less, the false aerosol concentration will be $\sim 1 \mathrm{ng} \mathrm{m}^{-3}$, and the error in $f_{44}$ will be less than $1 \%$ of its value (assuming a typical background concentration of OA of $1 \mu \mathrm{g} \mathrm{m}^{-3}$ and $f_{44}=15 \%$ ). For the large forest fire plumes observed in this study, $\mathrm{CO}_{2}$ is typically $390 \mathrm{ppm}$ (i.e. an enhancement of $10 \mathrm{ppm}$ above background values) while OA is $100 \mu \mathrm{g} \mathrm{m}^{-3}$ and $f_{44}$ is $10 \%$, and using the same method we estimate that the positive bias in OA due to this effect is $\sim 1 \mathrm{ng} \mathrm{m}^{-3}$, thus the positive bias in $f_{44}$ is $0.01 \%$ percent of its value. We do note that in some situations with low OA concentrations, and large $\mathrm{CO}_{2}$ variations due to ecosystem uptake and respiration, the constant correction discussed here is not sufficient (Chen et al., 2009). During ARCTAS the $m / z 44$ correction was applied using the time-series gas-phase $\mathrm{CO}_{2}$ measurements alongside the standard filter interpolation method; 
the two methods produced corrections values consistent to within $0.5 \%$.

Measurements with negligible BB influence were acquired during three ground-based field campaigns. Two urban datasets are presented, from Pasadena, CA, during the CalNex-LA campaign of 2010, and Riverside, CA, during the Study of Organic Aerosols at Riverside (SOAR-1) in 2005 (Docherty et al., 2008, 2011). The CalNex-LA campaign was a ground supersite located in the Caltech campus in Pasadena, CA, during 15 May to 15 June 2010. An HR-ToFAMS sampled ambient air during that period, with a very similar setup to the SOAR-1 measurements. Ambient sampling during CalNex was performed $5 \mathrm{~m}$ above ground level through a radiation-shielded, insulated inlet system. Large super-micron particles that are not transmitted through the AMS aerodynamic lens system, and can lead to clogging of orifices, were removed at the inlet head using a cyclone with $2.5 \mu \mathrm{m}$ size cut (URG-2000-30EN, http://www.urgcorp.com/ index.php/products/cyclones). To reduce particle losses, the inlet system was maintained under laminar flow conditions using mass-flow and critical-orifice control of the inlet flows, and split to the various instruments using dedicated stainless steel flow splitters (Brechtel Inc., http://www.brechtel.com). Standard sizing and ionization efficiency calibrations were performed regularly (Jimenez et al., 2003; Canagaratna et al., 2007, and references therein). Data were analysed using standard AMS data analysis software based on the algorithms in Jimenez et al. (2003), Allan et al. (2004) and DeCarlo et al. (2006). In addition, measurements are presented from a remote site at Blodgett Forest, CA, during the Biosphere Effects on Aerosols and Photochemistry Experiment (BEARPEX) of 2007 (Farmer et al., 2011). A period with variable $\mathrm{BB}$ impact as determined by several tracers has been removed from the BEARPEX dataset. Together, these measurements represent organic mass loadings from nearly zero to tens of $\mu \mathrm{g} \mathrm{m}^{-3}$.

Measurements in BB plumes were taken during research flights of the Arctic Research of the Composition of the Troposphere from Aircraft and Satellites (ARCTAS) mission of 2008 (Jacob et al., 2010). The ARCTAS data presented here were recorded aboard the NASA DC-8 platform and span locations above the North American continent from 35 to 90 degrees latitude and 150 to $12000 \mathrm{~m}$ in altitude. In addition to BB plumes advected thousands of kilometres from the Asian continent, near-field plumes were sampled from the mid-latitudes of California and the boreal forests of high-latitude Canada. These plumes came from a wide range of source fuels, meteorological and burn conditions, although the observed physical and chemical characteristics of the plumes were remarkably similar in nature (Singh et al., 2010). To ensure the capture of the true chemical nature of the BBOA, the AMS was operated through most plume penetrations in a new "Fast-MS" mode (FMS, Kimmel et al., 2011), with a time resolution of $1 \mathrm{~Hz}$ translating to an approximate geographical resolution of $100-200 \mathrm{~m}$.
Co-located gas-phase measurements taken on the DC-8 are also used in airmass classification. The University of Innsbruck Proton-Transfer- Reaction Mass-Spectrometer (PTRMS, Hansel et al., 1995; Wisthaler et al., 2002) measured, amongst other species, acetonitrile $\left(\mathrm{CH}_{3} \mathrm{CN}\right)$ for $1 \mathrm{~s}$ in every 5. The same species was also measured by the Trace Organic Gas Analyser (TOGA, Apel et al., 2003) instrument of the National Center for Atmospheric Research (NCAR). The NASA Langley Research Center measured Carbon Monoxide $(\mathrm{CO})$ at a rate of $1 \mathrm{~Hz}$ using a tunable diode-laser (Sachse et al., 1987). Ozone $\left(\mathrm{O}_{3}\right)$ was also measured at a $1 \mathrm{~Hz}$ rate by the NCAR 4-channel chemiluminescence instrument (Weinheimer et al.,1994). As such, the transition from background to plume conditions is apparent in the plume transect and edge effects can be eliminated.

Meteorological support during ARCTAS was led by Florida State University; we use here kinematic backtrajectories for plume transects for which the in-situ data is used in this analysis. The trajectories (http://fuelberg.met. fsu.edu/research/arctas/traj/traj.html) were based upon meteorological data from the Weather Research and Forecasting numerical model (Skamarock et al., 2008); for a detailed discussion the reader is referred to Fuelberg et al. (2010). The geographical extent and chemical evolution of BB plumes during ARCTAS was modeled by the Atmospheric Chemistry Modeling group at Harvard University using the GEOSChem chemical transport model v8-02-03 (http://geos-chem. org/), which has been extensively compared to aerosol and gas phase measurements from ARCTAS (Fisher et al., 2010; Fisher et al., 2011, Wang et al., 2011). The aerosol optical depth and $\mathrm{CO}$, in particular, are useful tracers within the model outputs for determining expected plume transects and $B B$ vs. non-BB contributions in the in-situ data.

AMS measurements of BBOA from controlled chamber open burning of specimens $(\sim 300 \mathrm{~g})$ were taken in the US Department of Agriculture Fire Sciences Laboratory, Missoula, MT, as part of the third Fire Lab at Missoula Experiment (FLAME-3) of 2009 (McMeeking et al., 2009). The BB smoke was diluted in a large chamber $\left(\sim 3000 \mathrm{~m}^{3}\right)$ where it stayed for $\sim 2 \mathrm{~h}$ and was gradually diluted with ambient air with much lower OA concentrations. Smoke from the chamber passed through an in-line photochemical reaction flow tube (a fourth generation Potential Aerosol Mass flow tube, or PAM, Kang et al., 2007, 2011) and was exposed to high concentrations of $\mathrm{OH}$, such that the integrated exposure was equivalent to hours to days of aging for typical atmospheric oxidant concentrations. With a residence time of $\sim 5 \mathrm{~min}$., the PAM flow tube allowed the study of aged POA and SOA in each burn for several "equivalent atmospheric ages", calibrated against $\mathrm{SO}_{2}$ decay, simulating the aging that may occur during advection from an ambient $\mathrm{BB}$ plume source region. Recent results indicate that the composition and hygroscopicity of the SOA produced by the PAM chamber resemble atmospheric OOA of variable to high aging (Kang et al., 2011; Massoli et al., 2010). We present here 
lumped measurements of the unprocessed POA and the photochemically processed POA/SOA mixture, for smoke from four different fuels in the fire chamber.

Finally, data are presented from multiple mass spectra from the AMS Spectral Database (Ulbrich et al., 2009b). These data were acquired by a number of groups, predominantly with the quadrupole version of the AMS. In particular, the measured spectra are presented from traditional environmental chamber studies of (a) SOA formed from exposing VOC precursors to oxidants (Bahreini et al., 2005; Liggio et al., 2005; Sage et al., 2008) and (b) POA from BB (Schneider et al., 2006; Weimer et al., 2008).

To provide context for the BB plumes observed over the Arctic in spring-time, an "Arctic-background" dataset was defined for ARCTAS-A (Spring), using co-located measurements to remove periods in intense biomass-burning plumes. Following the methodology of Wisthaler et al. (2009), the correlation of gas-phase acetonitrile to carbon monoxide was used in assessment of the different air mass types encountered (see Fig. S3 for further detail). In this study, the background data are accumulated after conservatively eliminating measurements according to a number of criteria. Data with $\mathrm{CO}>180 \mathrm{nmol} \mathrm{mol}^{-1}$ were eliminated, as $\mathrm{CO}$ is a known long-lived tracer for incomplete combustion of all kinds. Data with acetonitrile $>160 \mathrm{pmol} \mathrm{mol}^{-1}$ were eliminated. Values below this were determined by Wisthaler et al. to be "out-of-plume", and comfortably below the marked increase in concentrations noted in the upper quartile of the cumulative distribution functions for both the PTR-MS and TOGA instruments (shown in Fig. S4). To further filter out clear BB plumes, periods where the OA mass loading exceeded that of the omnipresent background sulphate are also removed, although this has little influence after application of the acetonitrile filter. To help reduce scatter due to noise in the data, all points with OA mass loading $<1 \mu \mathrm{g} \mathrm{s} \mathrm{m}^{-3}$ are eliminated. Finally, those data in the stratosphere (defined by $\mathrm{O}_{3} / \mathrm{CO}>1.25 \mathrm{~mol} \mathrm{~mol}^{-1}$, Hudman et al., 2007) and marine boundary layer (based on altitude) are eliminated. The remaining 252 measurement points, representing $\sim 250 \mathrm{~km}$ of aircraft flight range, were used to construct a so-called "Arctic background" dataset. The average parameters of interest were constructed for only four flights during ARCTAS-A because the rigorous screening process did not leave sufficient data in the rest of the flights to compose a meaningful average.

\section{Results and discussion}

\subsection{Levels of $f_{60}$ in air without biomass burning influence}

Figure 1 shows $f_{44}$ as a function of $f_{60}$ for the data of negligible BB-influence from SOAR-1, BEARPEX (BB-impacted period removed) and CalNex-LA, binned into quintile plots

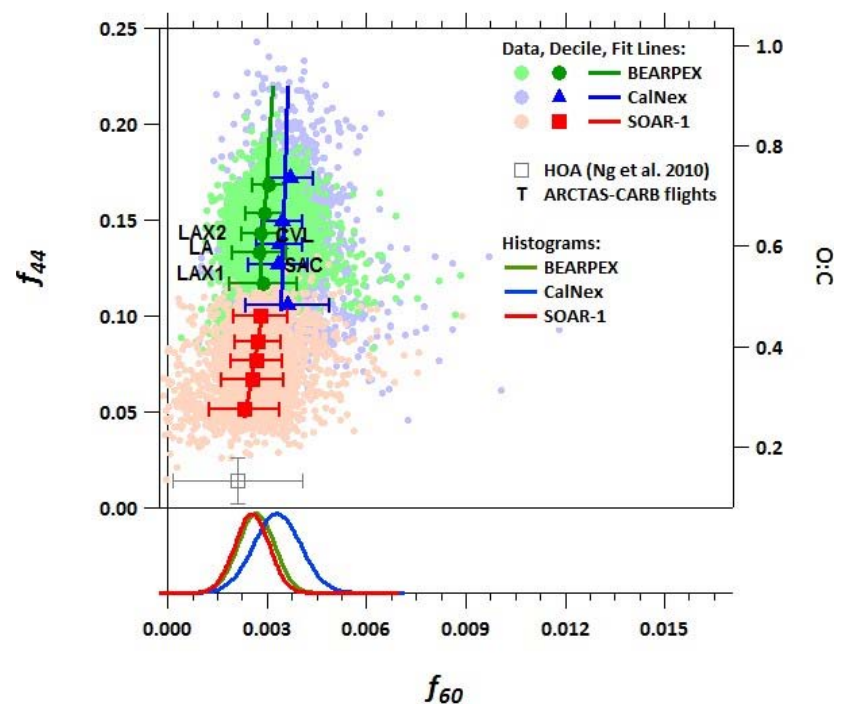

Fig. 1. Upper Panel: $f_{44}$ as a function of $f_{60}$ for measurements with little or negligible BB influence. Coloured points represent data from the ground campaigns SOAR-1, BEARPEX and CalNex-LA, and are also shown binned to quintiles for clarity. Text represents averaged periods from the ARCTAS-CARB mission: LA $=$ Los Angeles overpass, $\mathrm{LAX}=$ missed approach on $\mathrm{LAX}, \mathrm{CVL}=\mathrm{San}$ Joaquin valley, $\mathrm{SAC}=$ Sacramento overpass. Also shown is the average hydrocarbon-like OA across 15 urban studies (and its variability) from $\mathrm{Ng}$ et al. (2011b) for reference. Lower Panel: Normalised histograms of $f_{60}$ for the three ground campaigns. Note that the $f_{\mathrm{X}}$ quantities are dimensionless as they are ratios of two concentrations with the same units.

to exemplify the observed variations. The continuum of observed $f_{44}$ values suggests a range of oxidation states in the measured OA for these three campaigns, due to both coexistence of POA and SOA in air, as well as a variable degree of OOA oxidation (Jimenez et al., 2009; Ng et al., 2010). The representation of photochemical aging of SOA in a $f_{44}$ vs. $f_{43}$ diagram, in which $f_{44}$ increases and $f_{43}$ decreases with aging (the so-called "triangle plot", $\mathrm{Ng}$ et al., 2010, e.g. Fig. S5) allows a simplified description of SOA aging and comparison across studies. Similarly, the $f_{44}$ vs. $f_{60}$ plot is introduced here to map the formation and transformation of primary and secondary BBOA as BB plumes are advected from source to background regions. This analysis can be performed with data from any version of the AMS, including the newly developed monitoring version (ACSM, $\mathrm{Ng}$ et al., 2011b). Fig. 1 shows that for a wide range of states of oxidation, the measurements in air masses with negligible BB influence exhibit only a very small range in $f_{60}$, from about 0.2 to $0.4 \%$ of total OA. Such data form a broad vertical line in the $f_{44}$ vs. $f_{60}$ plot; the histograms for each of these three datasets are shown on the bottom panel of Fig. 1, and give median values of $0.25,0.27$ and $0.33 \%$ for SOAR- 1 , BEARPEX and CalNex-LA, respectively. 

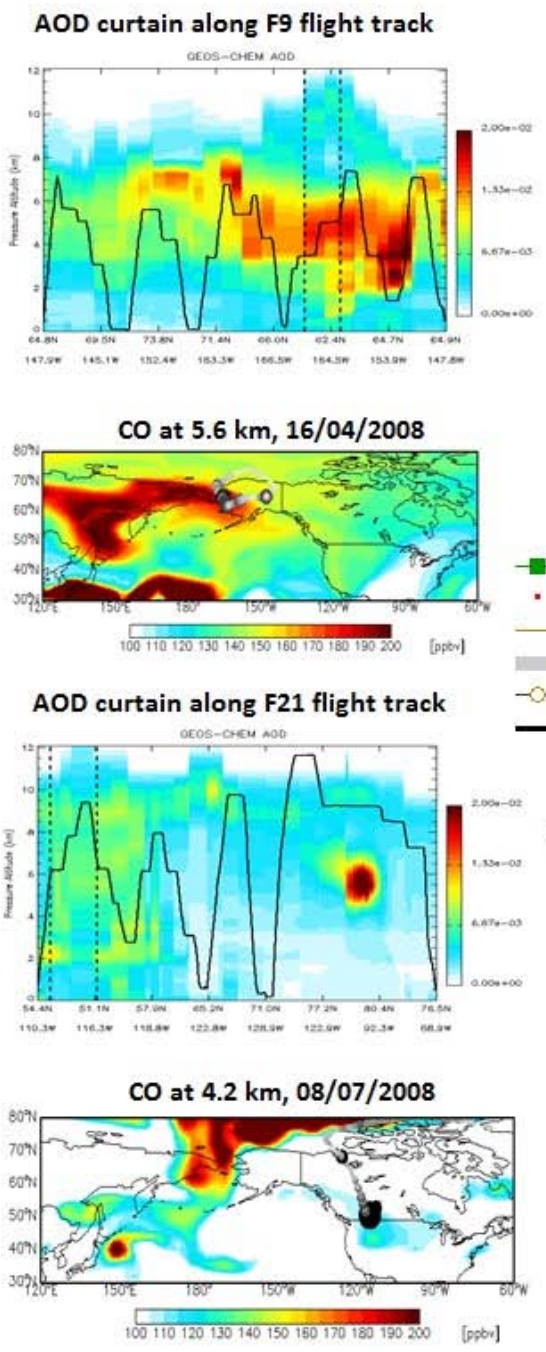

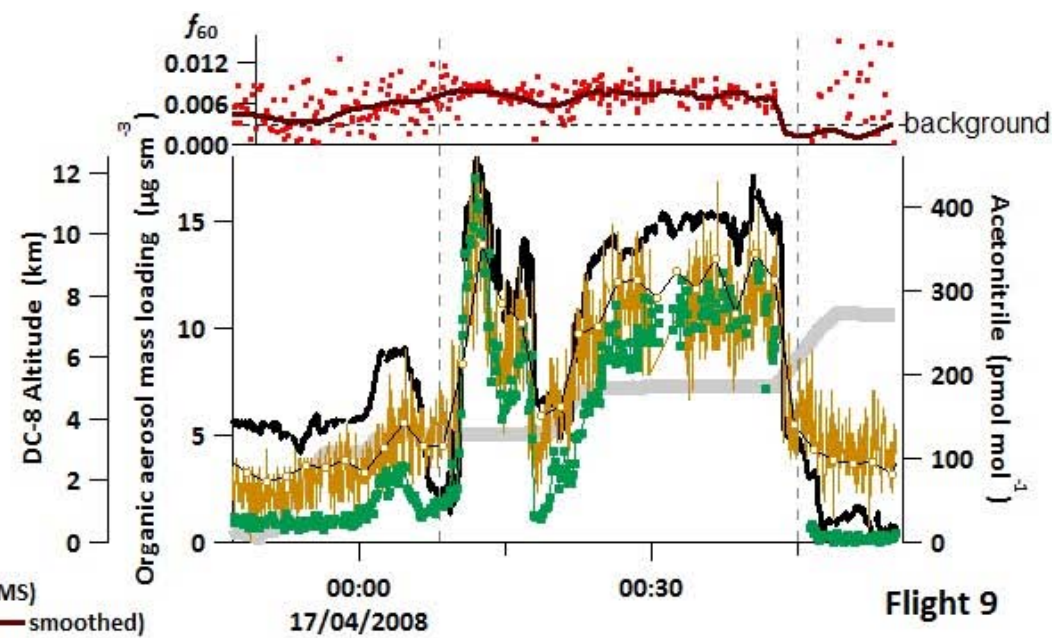

- $f_{60}$ (AMS)(- smoothed)

$-\mathrm{CH}_{3} \mathrm{CN}$ (PTR-MS)

Altitude (GPS)

$-\mathrm{CH}_{3} \mathrm{CN}$ (TOGA)

- CO (DACOM)
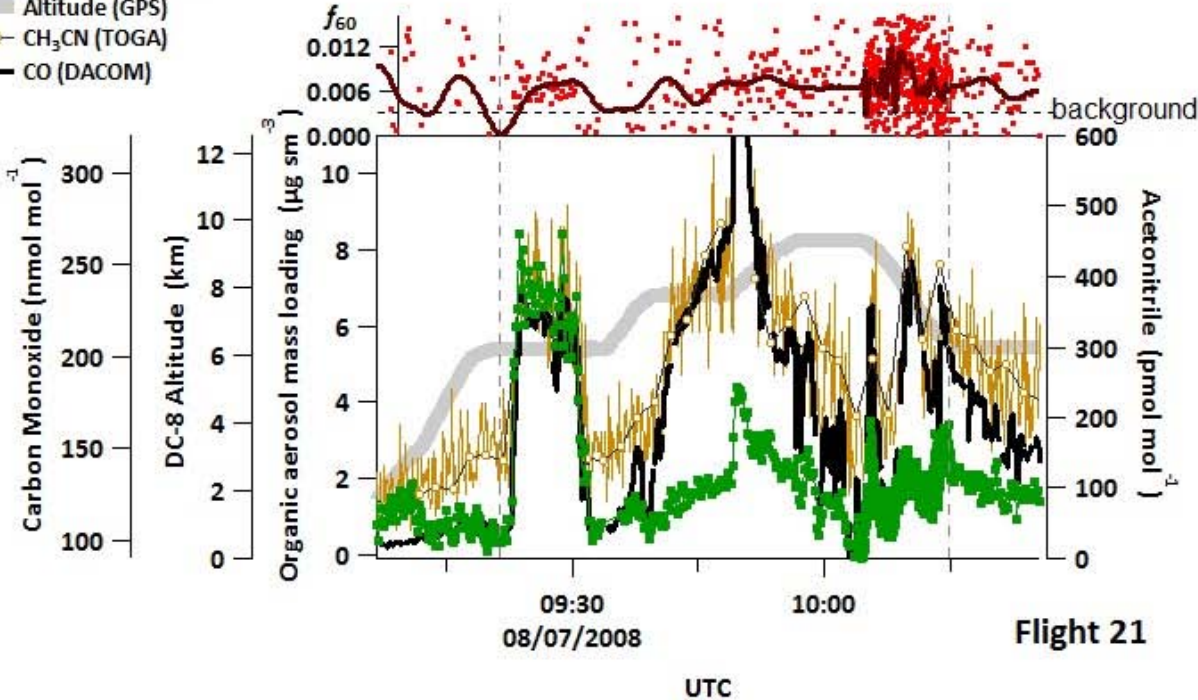

Fig. 2. Two long-range plumes intercepted during flight 9 of ARCTAS-A (top) and flight 21 of ARCTAS-B (bottom). Left panels: GEOSChem model output showing the aerosol optical depth curtain along the flight tracks with plume time-frames indicated by dashed lines (top), and global $\mathrm{CO}$ at a time and altitude relevant to the plume crossings (bottom). DC-8 flight tracks are also shown on the map, coloured and sized by gas-phase acetonitrile mixing ratio. Right panels: Time-series in-situ data for the plume transects aboard the DC- 8 aircraft, showing the increase in gas- and aerosol-phase species associated with the plumes predicted by the model. The plume time-frames are indicated by dashed lines.

In addition, data are also shown in Fig. 1 for five distinct periods during the California segment of the ARCTAS mission (ARCTAS-CARB), representing flyovers at or below $1000 \mathrm{ft}$ above ground level and within the mixed layer, during periods without forest fires, of Los Angeles and Los Angeles International Airport (LAX) (both on 12 June 2008), Sacramento and the California Central Valley (both on 14 June 2008). Several $\mu \mathrm{g} \mathrm{m}^{-3}$ of OA loading were observed at all these locations, but low average $f_{60}$ ratios are observed, in the range 0.1 to $0.4 \%$.

Thus, the $f_{60}$ tracer does not fall to zero for air without apparent BB influence, owing to the contributions at $m / z 60$ from non-BB sources. Fig. 1 demonstrates that, for the entire range of previously reported values of $f_{44}$, over a wide variety of atmospheric conditions, the previously applied metric of background $f_{60}=0.3 \%$ of OA is indeed appropriate.

\subsection{Observation of elevated $f_{60}$ in BB plumes transported thousands of kilometres}

The persistence of $f_{60}$ over long timescales is investigated looking at two separate BB plume case-studies from ARCTAS. Firstly, we present data from 16 April 2008, for the inter-continental transport to Alaska of BB plumes from fires burning in southern Russia, a straight-line distance of $\sim 6000 \mathrm{~km}$, although the actual eastward transport path was 


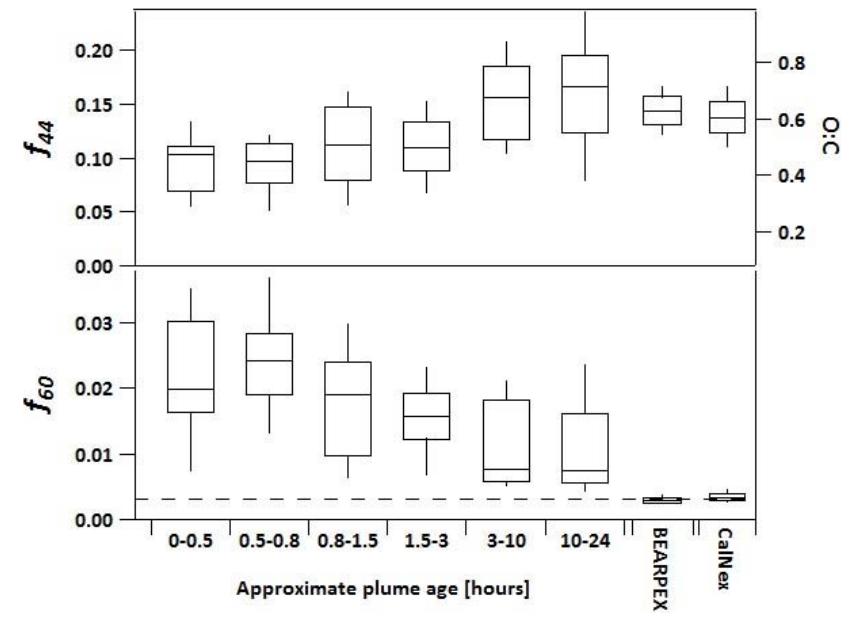

Fig. 3. Box and whisker plots representing the 10th, 25th, median, 75th and 90th percentiles for 245 BB plumes intercepted during ARCTAS. Classification of the plumes, and transport times shown on the horizontal axis, are adapted from Hecobian et al. (2011). Also shown are data from two ground campaigns free of BB influence.

in fact fairly complex and thus likely covered a substantially longer distance (Fuelberg et al., 2010). Secondly, we also present data from 8 July 2008, a separate case of inter-continental transport, from fires burning near and west of Beijing to western Canada, a straight-line distance of $\sim 8000 \mathrm{~km}$. These summer plumes followed a looped path across the Pacific, at much lower latitudes than the springtime event. Figure 2 shows the time-series of $f_{60}$, total OA and co-located gas-phase measurements across these plumes. The independent gas-phase tracers provide evidence that the intersected plumes are impacted by BB smoke, due to high levels and high correlation of BB tracers such as acetonitrile and CO. The in situ time-series data is also consistent with the model predictions of the BB plume transport shown on the left panels of Fig. 2. Back-trajectories from the plume transect points suggest that the sampled air-masses originated over the Asian continent in both cases; for a detailed discussion on the long-range transport of these, and other, plumes sampled during the ARCTAS mission, including parcel dispersion model output, see Fuelberg et al. (2010, their Figs. 12, 13, 23, 24).

The scatter in $f_{60}$ apparent in the low-loadings out-ofplume contrasts with the more consistent values, elevated above the $0.3 \%$ of OA background level, observed in the plumes (cf. Fig. 2, top panel). A key question for the usefulness of the $f_{60}$ tracer and the ability of the AMS to identify BB plumes in ambient air is "Does the oxidation of levoglucosan-like species in ambient BB plumes occur at a sufficient rate so as to decrease $f_{60}$ to background values before $f_{44}$ reaches the LV-OOA range? Or, does it persist for even very oxidised OOA?" Component deconvolution meth- ods such as PMF may identify subsets of OA if they comprise a sufficient fraction of the total, but their identification as BB plumes requires that $f_{60}$ of those components persists above background levels. In the cases presented in Fig. 2, the $f_{60}$ tracer indeed appears to persist after long advection and aging times in the atmosphere.

\subsection{Tracer evolution with aging for ambient BB plumes}

Hecobian et al. (2011) identified and classified 245 BB plumes intercepted by the NASA DC- 8 aircraft during ARCTAS-B, representing a wide range of source locations, fuels and meteorological conditions. These plumes were identified by coincident $\mathrm{CO}$ and $\mathrm{CO}_{2}$ enhancements of greater than twice the experimental uncertainty and longer than 4 seconds in length. Identified plumes were only classified as BB if the $R^{2}$ of correlation between $\mathrm{CO}$ and both $\mathrm{CH}_{3} \mathrm{CN}$ and $\mathrm{HCN}$ was greater than 0.6. An estimate of plume age was obtained from wind-vector analysis using aircraft GPS position and fire locations determined visually and through the Fire Information for Resource Management System (FIRMS). The uncertainty in plume age was estimated at $40 \%$. The reader is referred to Hecobian et al. (2011) for further details.

Despite the differences in the sources, the variation in $f_{60}$ and $f_{44}$ as a function of transport time of the plume from source is sufficiently strong so as to indicate trends in the data, as shown in Fig. 3. The plume $f_{60}$ values are in all cases substantially larger than the measured ratios during the campaigns unaffected by BB also shown on the plot. The observed $f_{44}$ in the plumes appears to increase into the LVOOA range on the timescale of approximately a day and, although the plume aerosol is a combination of primary and secondary components, the progression of its evolution in the $f_{44}$ vs. $f_{43}$ space falls within the expected range for ambient OOA (Ng et al., 2010) (Fig. S5). However, despite the increasingly oxygenated nature of the aged BBOA, $f_{60}$ remains above background levels for all the measured plumes. There is a clear contrast of the $f_{60}$ values measured in the ARCTAS plumes to those recorded during the BEARPEX and CalNex-LA campaigns; the latter measurements lie on the background $0.3 \%$ line and show little deviation from this value when compared to the difference with the BBinfluenced values. Thus for ambient BB plumes less than or around one day in transport time from the source region, Fig. 3 suggests that $f_{60}$ may be a robust tracer for $\mathrm{BB}$ for aging timescales of one day.

The decay of $f_{60}$ in ambient plumes from source to transport times of multiple days is represented in the $f_{44}$ vs. $f_{60}$ space in Fig. 4, showing the long-range plumes introduced in Fig. 2 together with all of the previously-discussed ambient $\mathrm{BB}$ plumes, and measurements of tropical agricultural residue BB plumes over the Yucatan peninsula reported in Yokelson et al. (2009). All the BB plume measurements exhibit a trend toward higher $f_{44}$ and lower $f_{60}$ values with age, 


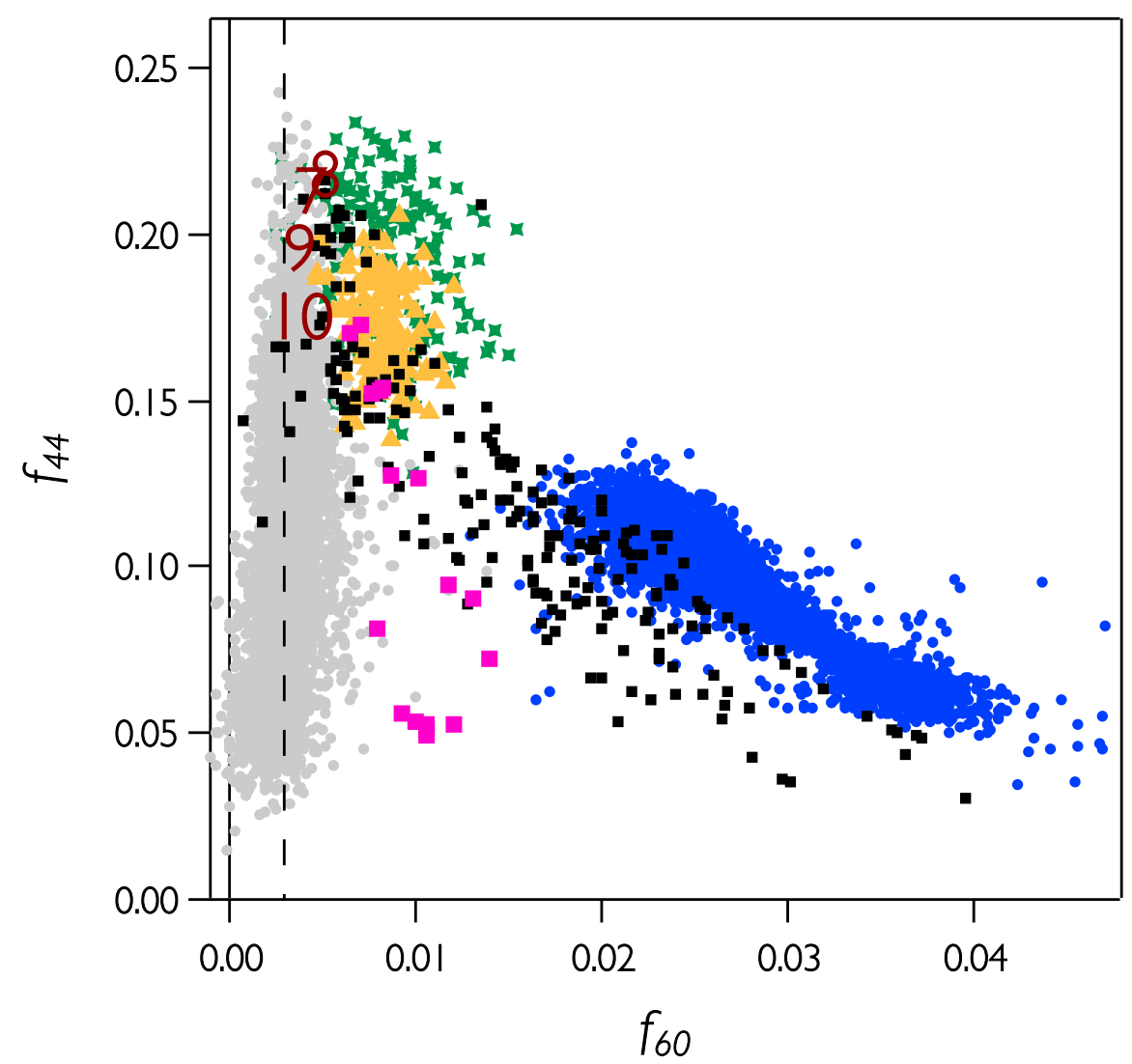

Data with negligible $B B$ influence

- SOAR / CalNex / BEARPEX

Data from fire plumes:

- Lake McKay, ARCTAS-B FI8

- All ARCTAS fire plumes

$\triangle$ Asian BB over NA, ARCTAS-A F9

- Asian BB over NA, ARCTAS-B F2I

- Yucatan, MILAGRO 2006

Data from the Arctic background

T ARCTAS-A Flights 7-10

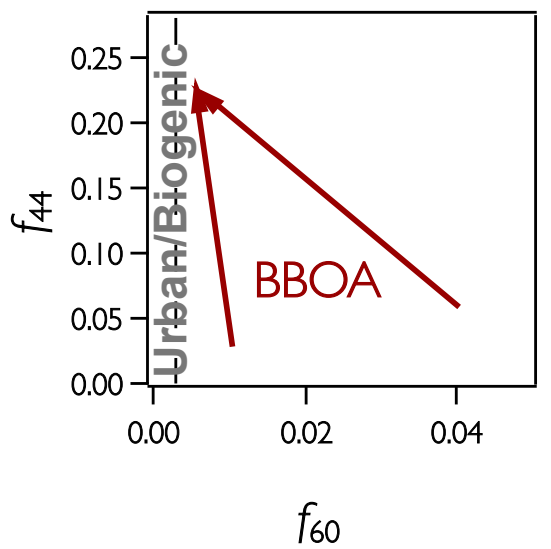

Fig. 4. Summary plot showing $f_{44}$ vs. $f_{60}$ for all the field measurements discussed in the text. The nominal background value at $0.3 \%$ is shown by the vertical dashed line. Right Panel: schematic of the different representations that the non-BB and BB data make in this space.

although the direction of the trends in the $f_{44}$ vs. $f_{60}$ space varies. The representation of the measurements in $f_{44} \mathrm{vs}$. $f_{60}$ space facilitates a direct comparison with the measurements from campaigns free of BB influence; this concept is mapped in the right panel of Fig. 4. Despite the widely varying conditions and number of BB plumes presented here, all exhibit a negative slope in this space upon aging. Given that the levoglucosan-like species that give rise to $f_{60}$ only contribute a small fraction of the OA mass, their contribution to the total signal $\mathrm{m} / \mathrm{z} 44$ before or after aging is also necessarily small. E.g. Aiken et al. (2009) show that levoglucosan only accounted for $6 \%$ of AMS-observed BBOA in Mexico City. As such, even when sampling smoke directly above a wildfire, where we can expect almost all OA to be classified as BBOA, the observed changes in $f_{44}$ are thus driven by oxidation of the bulk OA, and not just by the oxidation of levoglucosan and similar species. Thus the vertical axis in Fig. 4. is controlled by oxidation of the bulk OA, and the horizontal axis by oxidation of the levoglucosan-like species. The relative slopes of the different plume data then facilitate a comparison of the rates of oxidation of the OA as a whole to those of just the levoglucosan-like species. Consider $m$, the absolute slope of decay observed in the $f_{44}$ vs. $f_{60}$ space for a given set of measurements (i.e. $\Delta f_{44} / \Delta f_{60}$ ). In the extreme cases we have $m=\infty$ for the data with negligible BB influence, and the lowest values for the near-field data in the Lake McKay plume observed on 1 July 2008. The Lake MacKay fire burned in north-western Saskatchewan province, and was classified at the time of sampling as a surface-to-torching fire with a flame front traveling over $15 \mathrm{~km}$ per day at an intensity along the front of $9000 \mathrm{~kW} \mathrm{~m}^{-1}$, producing a very large plume that was intersected by the DC- 8 between 3000 and $6000 \mathrm{ft}$ altitude. This plume was followed downwind, exhibiting a similar value of $m$ to that for the lumped BB plumes observed during ARCTAS. Both show a similar increasing progression of $f_{44}$ during advection, but the Lake McKay plume was the most intense of those sampled on the project, and the levoglucosan-like content of the aerosol in the plume was the highest of all the ambient plumes. Notably, the tropical plumes from Yokelson et al. (2009) show a lower initial $f_{60}$ and a higher $m$, whilst still tending towards the same point in the $f_{44}$ vs. $f_{60}$ space as the boreal data. The endpoint for the most oxidised plumes within these data appears to be $f_{44} \sim 0.20-0.22$ (equivalent to $\mathrm{O}: \mathrm{C} \sim 0.9$ ). 


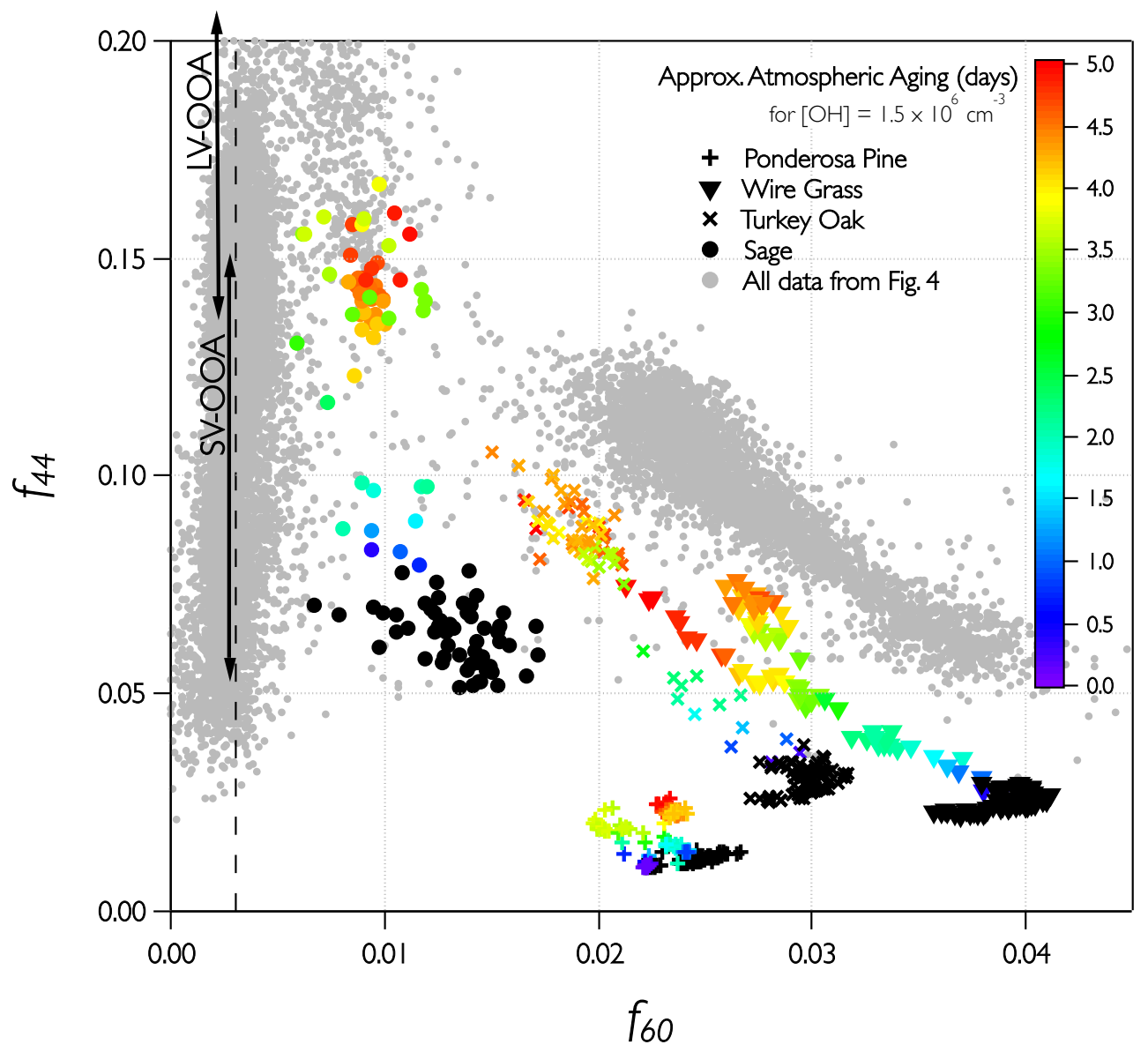

Fig. 5. $f_{44}$ vs. $f_{60}$ ratios for laboratory smoke during FLAME-3, and after processing with the Potential Aerosol Mass (PAM) flowtube. The colour scale indicates the estimated processing time of the aerosol in the flowtube, after normalisation to the stated $1.5 \times 10^{6}$ atmospheric $[\mathrm{OH}]$ level. The background $f_{60}$ level of $0.3 \%$ of $\mathrm{OA}$ is indicated by the dashed line in the figure and the data from the negligible-BB campaigns SOAR-1, BEARPEX and CalNex are also shown. The typical oxidation range exhibited by ambient SV-OOA and LV-OOA is indicated with the vertical arrows.

From Fig. 4, it appears as though $m$ increases slightly for more oxidised aerosol (so $f_{60}$ appears to change less for the same change in $f_{44}$ ). This increase is perhaps due to the combination of a near exponential decay of levoglucosanlike species (Hennigan et al., 2010; Hoffmann et al., 2010) with the more linear increase in $f_{44}$ with age. The potential elevation of the endpoint in $f_{60}$ above background levels will be discussed later.

\subsection{Tracer evolution in laboratory aging of BB emissions}

We investigate here the evolution of $f_{44}$ and $f_{60}$ in mass spectra of fresh and aged OA smoke from controlled burns during the FLAME-3 campaign, after aging in the PAM photochemical oxidation flow tube. The progression of these metrics as a function of the equivalent atmospheric age is shown in Fig. 5. The trends are very similar to those observed for the field data in Fig. 4. $f_{44}$ increases with aging, as oxidation of the BB-POA and/or SOA formation in the PAM flow-tube trends the overall OA oxidation state into the SV-OOA range. $f_{60}$ is reduced by oxidation in most cases, although all the measurements lie well above the $0.3 \%$ background level, but the different fuels also exhibit very different degrees of change and trajectories (slopes) in $f_{44}$ vs. $f_{60}$ space. The direction of the trends, however, is similar to the field data and always toward the top-left corner of the plot, a progression of BBOA oxidation toward the SV- and LV-OOA range.

The timescales of oxidation observed here are considerably slower than those reported by the lab study of Hennigan et al. (2010) for levoglucosan. For a constant OH concentration of $1.5 \times 10^{6}$ molecules $\mathrm{cm}^{-3}$, Hennigan et al. (2010) report a mean 1/e lifetime for levoglucosan in BB particles of $18 \mathrm{~h}$. Timescales of the same order are consistent with the $f_{60}$ decay for the ARCTAS data shown in Fig. 3. However the fastest $f_{60}$ decay observed in PAM during FLAME-3, that of the Wire Grass, leads to an estimated lifetime of $\sim 5$ days 


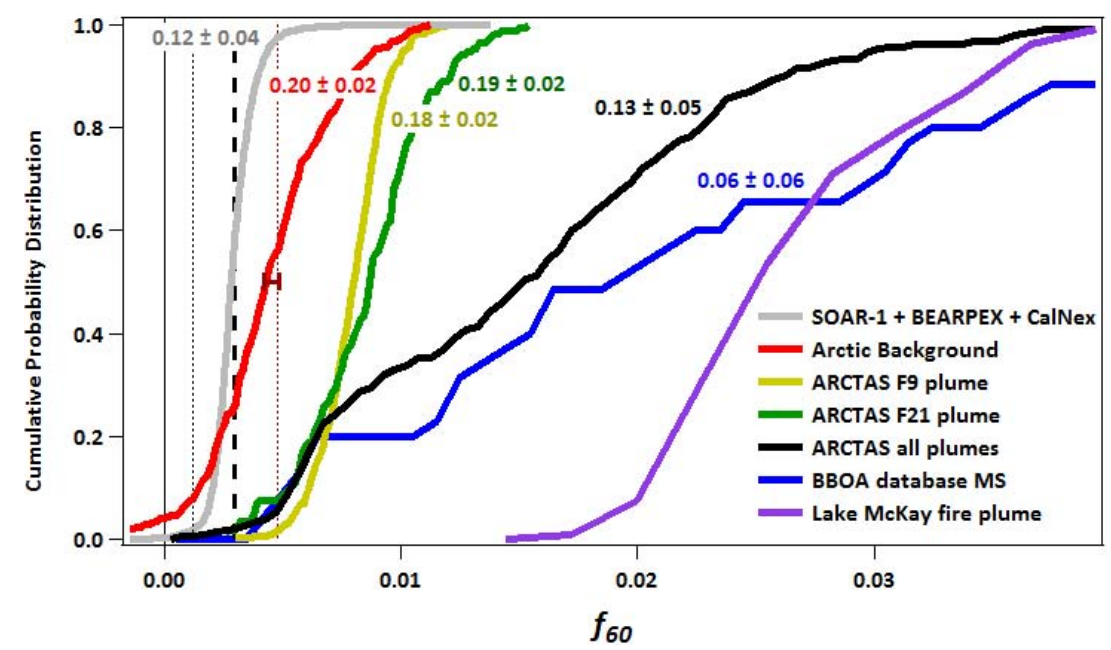

Fig. 6. Cumulative probability distributions of $f_{60}$ from multiple datasets. The nominal background value at $0.3 \%$ is shown by the thick dashed line, and the 3-sigma widths of the negligible-BB datasets by the thin dashed lines. The mean \pm standard error for the "Arcticbackground" dataset are indicated by the horizontal red bar. The mean and standard deviation of the $f_{44}$ value for each dataset is indicated on the plot.

under the same conditions. We note that the one case of decay of $m / z 60$ shown by Hennigan et al. (2010) also shows a timescale much longer than $18 \mathrm{~h}$. The reason for the longer lifetimes observed in our study vs. that of Hennigan et al. are unclear. $f_{60}$ contains contributions from molecules other than levoglucosan (Aiken et al., 2009; Lee et al., 2010), and perhaps other molecules do not decay as fast as levoglucosan does. It is also possible that differences in particle phase between the lab and ambient data, or the higher concentrations used in our experiments, may have also shielded some of the levoglucosan-like species from oxidation.

\subsection{Evaluation of background levels of $f_{60}$ for diluted and aged BB plumes}

In this section we evaluate whether an $f_{60}$ signature above background persists for some of the most aged data with biomass burning influence observed in our aircraft studies, those within the "Arctic-background" air-masses of ARCTAS-A (Spring). Warneke et al. (2010, their Fig. 2) show single-particle measurements from the NOAA P-3 aircraft during the co-located ARCPAC campaign (Brock et al., 2011), concluding that particles containing BB material dominated the distribution above the boundary layer during ARCPAC. In addition, the air masses transported to the Arctic are known to have been trapped within the polar high and thus exposed to exceptionally long processing times (Fuelberg et al., 2010). As such, the Arctic-background data is highly aged and oxygenated in nature; represented as flightaverages in the triangle space of $\mathrm{Ng}$ et al. (2010), it reaches values close to the ultimate state of oxidation observed for ambient data (Fig. S5). Thus, this Arctic-background air, even if not entirely representative of the true Arctic back- ground owing to the targeted nature of the research flights, is nonetheless considered a good example of oxygenated background OA containing a fraction of oxidised BB POA and/or SOA from precursors of $\mathrm{BB}$ origin. In the $f_{44}$ vs. $f_{60}$ space of Fig. 4, the Arctic-background OA show high oxidation and relatively low $f_{60}$ values, compared to the long-range plume of flight 9 , and can be considered as an endpoint in this space of the evolution in BBOA. The question pertinent here is "Does this endpoint lie elevated in $f_{60}$ with respect to the $0.3 \%$ of OA background level, or is this BB signature completely lost for such prolonged aging?"

This question is addressed through comparison of the observed cumulative probability distribution functions $(\mathrm{CDFs})$ of $f_{60}$ in $\mathrm{BB}$ plumes, the Arctic-background data and the negligible-BB data from the ground campaigns, as shown in Fig. 6. Combining the measurements from the three ground campaigns, the mean $f_{60}$ value is $0.3 \%$ with a standard deviation of $0.06 \%$ (absolute); both the mean nominal background value and the three-sigma limits are shown in Fig. 6. The CDFs of the non-BB data, the two long-range plumes and the combined ARCTAS plume data are distinct in $f_{60}$ space. Virtually all of the measurements of $f_{60}$ from the long-range plumes lie above the average plus $3 \sigma$ of the background level. $f_{60}$ for near-field, less-oxidised, BBOA measurements, represented by BBOA spectra from the AMS database and the Lake McKay fire plume from ARCTAS-B, are even more separated from the background level.

Less elevated in $f_{60}$ than the plumes, but with mean values elevated above and statistically separable from those of the ground-campaign data, is the data from the "Arcticbackground" dataset. The reader is reminded that "background" in this context refers to the omnipresent, disperse OA observed out-of-plume in the Arctic spring, and the $f_{60}$ 


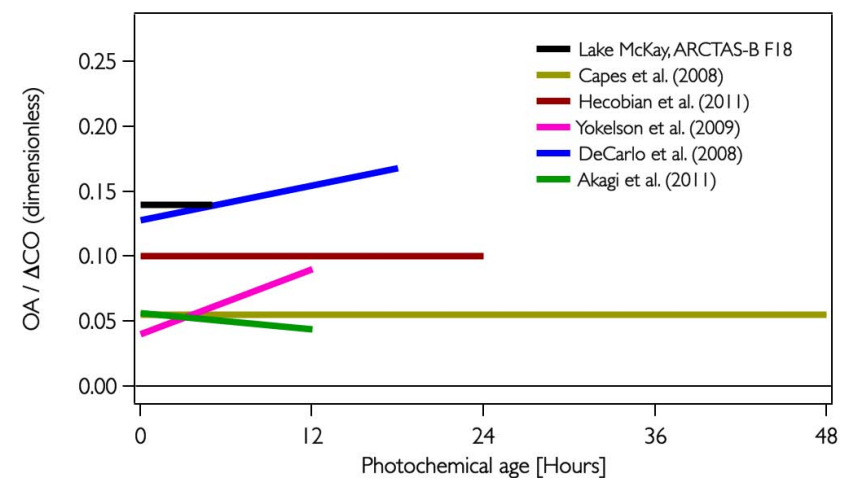

Fig. 7. Schematic summarising, for the available field BB datasets presented here and in the literature, the organic aerosol (OA) concentration observed as a function of plume age, normalised to the enhancement in $\mathrm{CO}$ concentration above its background. Photochemical age is the number of hours with an $\mathrm{OH}$ exposure of $1.5 \times 10^{6}$ that produce the same total estimated $\mathrm{OH}$ exposure of the field data.

exhibited by this dataset is distinct from the $f_{60}$ background level of $0.3 \%$ discussed earlier. The statistical separation of the two, although small, suggests consistency with Warneke et al. $(2009,2010)$, in that BBOA represented a significant fraction of the total OA burden during the 2008 Arctic spring, even outside of the clear BB plumes.

\subsection{Net enhancement of OA mass due to BB plume aging: compilation of field data and global budget estimate}

We summarise here results from this study and the literature on the measured OA with aging of evolving ambient open BB plumes (Capes et al., 2008; Yokelson et al., 2009; Akagi et al., 2011; DeCarlo et al., 2010; Hecobian et al., 2011). We define POA as the mass of OA directly emitted from a wildfire in the particle phase. Figure 7 shows that total primary OA (POA) mass, once normalised to excess $\mathrm{CO}$ (above background) mass concentration to remove the effect of dilution, is highly variable for the six datasets presented, consistent with the variability in BB POA emissions from previous literature reports (e.g. de Gouw and Jimenez, 2009; Akagi et al., 2011). The variability in POA/ $\Delta \mathrm{CO}$ is not only seen across the different studies, but also within the ARCTAS-B dataset utilised in this work (based on the plume transects classified by Hecobian et al., 2011), for which $\mathrm{OA} / \Delta \mathrm{CO}$ ranges from $\sim 0.02$ to $0.25 \mathrm{~g} \mathrm{~g}^{-1}$, independent of plume age but highly variable between plumes. The Lake McKay plume sampled on 1 July 2008 was particularly well characterised, exhibiting an invariant linear relationship between $\mathrm{OA}$ and $\mathrm{CO}$ enhancements of $\mathrm{OA} / \Delta \mathrm{CO} \sim 0.14 \mathrm{~g} \mathrm{~g}^{-1}$. In contrast, the data from the Yucatan agricultural fires of Yokelson et al. (2009) suggested a substantial enhancement in $\mathrm{OA} / \Delta \mathrm{CO}$ with plume age owing to SOA production. DeCarlo et al. (2010) also quantified an enhancement of $\mathrm{OA} / \Delta \mathrm{CO}$ with aging for forest fire plumes near Mexico City. Finally Akagi et al. (2011) observed a small decrease in $\mathrm{OA} / \triangle \mathrm{CO}$ with aging for brush fires in California. Aging of controlled-burn chamber data during FLAME-3 with two different experimental setups also resulted in a highly variable net $\mathrm{OA}$ enhancement, depending (among other parameters) on fuel type and burn conditions (Hennigan et al., 2011; Ortega, 2010), which appears consistent with the large degree of variability observed in the ambient datasets.

We can provide a first estimate of the global source of $\mathrm{OA}$ due to aging of open $\mathrm{BB}$ plumes by two complementary methods. We define $\triangle \mathrm{OA}$ as the net enhancement of $\mathrm{OA}$, with respect to the amount that would be present in the absence of physical and chemical aging. This net enhancement combines the effects of POA evaporation and SOA formation. For the first method, we calculate the average net enhancement of OA due to aging, normalized by excess $\mathrm{CO}$ (above its regional background level, to remove the effect of dilution) for the six field studies summarized in Fig. 7. $\Delta \mathrm{OA} / \triangle \mathrm{CO}$ after aging is calculated by subtracting the average of $\mathrm{OA} / \triangle \mathrm{CO}$ in aged air from the $\mathrm{POA} / \Delta \mathrm{CO}$ ratio determined for each case. Note that this calculation does not use $f_{44}, f_{60}$, or any other AMS chemical tracer. $\triangle \mathrm{OA} / \Delta \mathrm{CO}$ during field aging ranges from -0.01 to $0.05 \mathrm{~g} \mathrm{~g}^{-1}$, with an average of $0.013 \pm 0.011$ (std. error of the mean) $\mathrm{g} \mathrm{g}^{-1}$. We then multiply this net enhancement by the IPCC CO emissions for biomass burning ( $\left.508 \mathrm{Tg} \mathrm{CO} \mathrm{yr}^{-1}\right)$ to obtain an estimate of the global net source of OA due to aging of biomass burning plumes, as $7 \pm 6 \mathrm{Tg} \mathrm{yr}^{-1}$. A second estimate can be obtained in a similar way, but using the POA emissions from biomass burning as the normalizing variable, instead of gasphase $\mathrm{CO}$. The average ratio of the net $\mathrm{OA}$ enhancement to POA, $\triangle \mathrm{OA} / \mathrm{POA}$ is $0.19 \pm 0.18 \mathrm{~g} \mathrm{~g}^{-1}$ for the combined six sets of aircraft measurements. Combining the average increase in $\triangle \mathrm{OA} / \mathrm{POA}$ with the global emission inventory of BB POA (41 Tg yr${ }^{-1}$, de Gouw and Jimenez, 2009), we obtain an alternative estimate of the global net source of OA from $\mathrm{BB}$ aging as $8 \pm 7 \mathrm{Tg} \mathrm{yr}^{-1}$. With respect to the overall global OA budget, estimated at $\sim 150-300 \mathrm{Tg} \mathrm{yr}^{-1}$ (Hallquist et al., 2009; Spracklen et al., 2011), the estimated OA source from net SOA formation in BB smoke aging of $\sim 7-8 \mathrm{Tg} \mathrm{yr}^{-1}$ is of the order of $5 \%$ of the total global OA source. Thus secondary OA production in BB plumes could represent an important global source of OA. However, more field measurements are required to better constrain the magnitude, frequency of occurrence, and controlling parameters of net SOA production in $\mathrm{BB}$ plumes.

\section{Conclusions}

Using HR-ToF-AMS data of negligible BB influence from three field campaigns, it has been shown that an appropriate background level of the $f_{60}$ tracer is $0.3 \%$ of OA. 
Furthermore, the contribution in signal at unit mass $m / z 60$ arises virtually entirely from a single ion, $\mathrm{C}_{2} \mathrm{H}_{4} \mathrm{O}_{2}^{+}$, allowing the analysis presented here to be performed using UMR data and thus extended to the lower resolution versions of the AMS or the recently developed Aerodyne aerosol chemical speciation monitor (ACSM, Ng et al., 2011a).

A novel method for representing the aging of BBOA in the atmosphere uses the $f_{44}$ vs. $f_{60}$ space, which shows the increasing oxidation of the OA ensemble in parallel with the oxidative decay of the levoglucosan-like species emitted as primary aerosol during BB. Measurements of several hundred ambient BB plumes exhibit $f_{60}$ levels above background and negative slopes in $f_{44}$ vs. $f_{60}$ space. This behaviour was seen for plumes measured over three continents, with some close to the source and some transported from sources many days away. These measurements contrast with measurements free from BB influence which exhibit a similar progression in oxidation and thus $f_{44}$, but display much more uniform $f_{60}$ values, close to the $0.3 \%$ background level. The relative rate of decay of $f_{60}$ in ambient BB plumes, as compared to the oxidation of the bulk OA, is shown to differ between plumes. Oxidation flowtube data from controlled burns, known to be exclusively BBOA and aged using an inline reaction flow-tube, resulted in a similar progression of BBOA during aging in the $f_{44}$ vs. $f_{60}$ space. The BBOA was observed in some cases to evolve to $f_{44}$ values associated with the LV-OOA subtype, but in all cases maintained $f_{60}$ values significantly above background for all the flow chamber measurements.

Statistical analysis of the data shows that BB plumes, even those having undergone multiple days worth of atmospheric oxidation, exhibit $f_{60}$ values elevated by a statisticallysignificant level with respect to the negligible-BB campaign datasets. Whilst consecutive individual measurements may only retain $f_{60}>0.3 \%$ in sampling of clear BB plumes, it is proposed that cumulative distribution functions of $f_{60}$ may be used together with representation in $f_{44}$ vs. $f_{60}$ space to make a general, qualitative, statement about the prevalence of BBOA as a component of OA in AMS mass-spectra. Thus whilst not inert, $f_{60}$ appears to be a persistent tracer, and quantitative analysis of its prevalence in sub-groups of OA should be the subject of future research addressing sourcereceptor relationships.

A first synthesis of the limited field measurements of net OA production in ambient BB plumes was presented. There is large variability in the observed values as normalised to $\mathrm{CO}$ or POA emission. Taking a simple average of the six available datasets shows that aging of open BB smoke may produce $\sim 8 \mathrm{Tg} \mathrm{OA} \mathrm{yr}^{-1}$, of the order of $5 \%$ of the global OA burden, making this a potentially important atmospheric OA source.

\section{Supplement related to this article is available online at: http://www.atmos-chem-phys.net/11/12049/2011/ acp-11-12049-2011-supplement.pdf.}

Acknowledgements. The authors would like to extend thanks to the entire ARCTAS science and operational teams for their diligent and much-appreciated efforts before, during and after the mission. Stephanie Vay of NASA Langley is acknowledged for contributing her $\mathrm{CO}_{2}$ data for our responses to the reviews. We acknowledge the following grants: NASA NNX08AD39G, EPA grant R833747, DOE (BER/ASR Program) DE-SC0006035, and CARB-08-319. AMO was partially supported by a DOE SCGF Fellowship (ORAU, ORISE, DE-AC05-06OR23100). PTR-MS measurements were supported by the PTR-MS Promotion Agency (FFG-ALR) and the Tiroler Zukunftsstiftung, and were carried out with the help/support of M. Graus, A. Hansel and T. D. Maerk.

Edited by: K. Law

\section{References}

Aiken, A. C., DeCarlo, P. F., and Jimenez, J. L.: Elemental Analysis of Organic Species with Electron Ionization HighResolution Mass Spectrometry, Anal. Chem., 79, 8350-8358, doi:10.1021/ac071150w, 2007.

Aiken, A. C., Salcedo, D., Cubison, M. J., Huffman, J. A., DeCarlo, P. F., Ulbrich, I. M., Docherty, K. S., Sueper, D., Kimmel, J. R., Worsnop, D. R., Trimborn, A., Northway, M., Stone, E. A., Schauer, J. J., Volkamer, R. M., Fortner, E., de Foy, B., Wang, J., Laskin, A., Shutthanandan, V., Zheng, J., Zhang, R., Gaffney, J., Marley, N. A., Paredes-Miranda, G., Arnott, W. P., Molina, L. T., Sosa, G., and Jimenez, J. L.: Mexico City aerosol analysis during MILAGRO using high resolution aerosol mass spectrometry at the urban supersite (T0) - Part 1: Fine particle composition and organic source apportionment, Atmos. Chem. Phys., 9, 66336653, doi:10.5194/acp-9-6633-2009, 2009.

Aiken, A. C., de Foy, B., Wiedinmyer, C., DeCarlo, P. F., Ulbrich, I. M., Wehrli, M. N., Szidat, S., Prevot, A. S. H., Noda, J., Wacker, L., Volkamer, R., Fortner, E., Wang, J., Laskin, A., Shutthanandan, V., Zheng, J., Zhang, R., Paredes-Miranda, G., Arnott, W. P., Molina, L. T., Sosa, G., Querol, X., and Jimenez, J. L.: Mexico city aerosol analysis during MILAGRO using high resolution aerosol mass spectrometry at the urban supersite (T0) -Part 2: Analysis of the biomass burning contribution and the non-fossil carbon fraction, Atmos. Chem. Phys., 10, 5315-5341, doi:10.5194/acp-10-5315-2010, 2010.

Akagi, S. K., Craven, J. S., Taylor, J. W., McMeeking, G. R., Yokelson, R. J., Burling, I. R., Urbanski, S. P., Wold, C. E., Seinfeld, J. H., Coe, H., Alvarado, M. J., and Weise, D. R.: Evolution of trace gases and particles emitted by a chaparral fire in California, Atmos. Chem. Phys. Discuss., 11, 22483-22544, doi:10.5194/acpd-11-22483-2011, 2011.

Alfarra, M. R., Coe, H., Allan, J. D., Bower, K. N., Boudries, H., Canagaratna, M. R., Jimenez, J. L., Jayne, J. T., Garforth, A., Li, S. M., and Worsnop, D. R.: Characterization of Urban and Regional Organic Aerosols In the Lower Fraser Valley Using Two Aerodyne Aerosol Mass Spectrometers, Atmos. Environ., 38, 5745-5758, 2004. 
Alfarra, M. R., Prevot, A. S. H., Szidat, S., Sandradewi, J., Weimer, S., Lanz, V. A., Schreiber, D., Mohr, M., and Baltensperger, U.: Identification of the mass spectral signature of organic aerosols from wood burning emissions, Environ. Sci. Technol., 41, 57705777, 2007.

Allan, J. D., Coe, H., Bower, K. N., Alfarra, M. R., Delia, A. E., Jimenez, J. L., Middlebrook, A. M., Drewnick, F., Onasch, T. B., Canagaratna, M. R., Jayne, J. T. and Worsnop, D. R: Technical Note: Extraction of Chemically Resolved Mass Spectra from Aerodyne Aerosol Mass Spectrometer Data, J. Aerosol Sci., 35, 909-922, 2004.

Apel, E. C., Hills, A. J., Lueb, R., Zindel, S., Eisele, S., and Riemer, D. D.: A fast-GC/MS system to measure C-2 to C-4 carbonyls and methanol aboard aircraft, J. Geophys. Res., 108, D8794, doi:10.1029/2002JD003199, 2003.

Bahreini, R., Keywood, M. D., Ng, N. L., Varutbangkul, V., Gao, S., Flagan, R. C., Seinfeld, J. H., Worsnop, D. R., and Jimenez, J. L.: Measurements of Secondary Organic Aerosol (SOA) from oxidation of cycloalkenes, terpenes, and m-xylene using an Aerodyne Aerosol Mass Spectrometer, Environ. Sci. Technol., 9, 56745688, doi:10.1021/es048061a, 2005.

Bond, T. C., Streets, D. G., Yarber, K. F., Nelson, S. M., Woo, J. H., and Klimont, Z.: A technology-based global inventory of black and organic carbon emissions from combustion, J. Geophys. Res., 109, D14203, doi:10.1029/2003JD003697, 2004.

Brock, C. A., Cozic, J., Bahreini, R., Froyd, K. D., Middlebrook, A. M., McComiskey, A., Brioude, J., Cooper, O. R., Stohl, A., Aikin, K. C., de Gouw, J. A., Fahey, D. W., Ferrare, R. A., Gao, R.-S., Gore, W., Holloway, J. S., HÜbler, G., Jefferson, A., Lack, D. A., Lance, S., Moore, R. H., Murphy, D. M., Nenes, A., Novelli, P. C., Nowak, J. B., Ogren, J. A., Peischl, J., Pierce, R. B., Pilewskie, P., Quinn, P. K., Ryerson, T. B., Schmidt, K. S., Schwarz, J. P., Sodemann, H., Spackman, J. R., Stark, H., Thomson, D. S., Thornberry, T., Veres, P., Watts, L. A., Warneke, C., and Wollny, A. G.: Characteristics, sources, and transport of aerosols measured in spring 2008 during the aerosol, radiation, and cloud processes affecting Arctic Climate (ARCPAC) Project, Atmos. Chem. Phys., 11, 2423-2453, doi:10.5194/acp-11-24232011, 2011.

Canagaratna, M. R., Jayne, J. T., Jimenez, J. L., Allan, J. D., Alfarra, M. R., Zhang, Q., Onasch, T. B., Drewnick, F., Coe, H., Middlebrook, A., Delia, A., Williams, L. R., Trimborn, A. M., Northway, M. J., DeCarlo, P. F., Kolb, C. E., Davidovits, P., and Worsnop, D. R.: Chemical and Microphysical Characterization of Ambient Aerosols with the Aerodyne Aerosol Mass Spectrometer, Mass Spectrom. Rev., 26, 185-222, 2007.

Capes, G., Johnson, B., McFiggans, G., Williams, P. I., Haywood, J., and Coe, H.: Aging of Biomass Burning Aerosols Over West Africa: Aircraft Measurements of Chemical Composition, Microphysical Properties, and Emission Ratios. J. Geophys. Res., 113, D00C15, doi:10.1029/2008JD009845, 2008.

Cappa, C. D. and Jimenez, J. L.: Quantitative estimates of the volatility of ambient organic aerosol, Atmos. Chem. Phys., 10, 5409-5424, doi:10.5194/acp-10-5409-2010, 2010.

Chen, Q., Farmer, D. K., Schneider, J., Zorn, S. R., Heald, C. L., Karl, T. G., Guenther, A., Allan, J. D., Robinson, N., Coe, H., Kimmel, J. R., Pauliquevis, T., Borrmann, S., Pöschl, U., Andreae, M. O., Artaxo, P., Jimenez, J. L., and Martin, S. T.: Mass Spectral Characterization of Submicron Biogenic Organic Par- ticles in the Amazon Basin, Geophys. Res. Lett., 36, L20806, doi:10.1029/2009GL039880, 2009.

DeCarlo, P. F., Kimmel, J. R., Trimborn, A., Northway, M. J., Jayne, J. T., Aiken, A. C., Gonin, M., Fuhrer, K., Horvath, T., Docherty, K., Worsnop, D. R., and Jimenez, J. L.: Fielddeployable, high-resolution, time-of-flight aerosol mass spectrometer, Anal. Chem. 78, 8281-8289, 2006.

DeCarlo, P. F., Dunlea, E. J., Kimmel, J. R., Aiken, A. C., Sueper, D., Crounse, J., Wennberg, P. O., Emmons, L., Shinozuka, Y., Clarke, A., Zhou, J., Tomlinson, J., Collins, D. R., Knapp, D., Weinheimer, A. J., Montzka, D. D., Campos, T., and Jimenez, J. L.: Fast airborne aerosol size and chemistry measurements above Mexico City and Central Mexico during the MILAGRO campaign, Atmos. Chem. Phys., 8, 4027-4048, doi:10.5194/acp8-4027-2008, 2008.

DeCarlo, P. F., Ulbrich, I. M., Crounse, J., de Foy, B., Dunlea, E. J., Aiken, A. C., Knapp, D., Weinheimer, A. J., Campos, T., Wennberg, P. O., and Jimenez, J. L.: Investigation of the sources and processing of organic aerosol over the Central Mexican Plateau from aircraft measurements during MILAGRO, Atmos. Chem. Phys., 10, 5257-5280, doi:10.5194/acp-10-52572010, 2010.

de Gouw, J. and Jimenez, J. L.: Organic Aerosols in the Earth's Atmosphere, Environ. Sci. Technol., 43, 7614-7618, doi:10.1021/es9006004, 2009.

Docherty, K. S., Stone, E. A., Ulbrich, I. M., DeCarlo, P. F., Snyder, D. C., Schauer, J. J., Peltier, R. E., Weber, R. J., Murphy, D. M., Seinfeld, J. H., Grover, B. D., Eatough, D. J., and Jimenez, J. L.: Apportionment of Primary and Secondary Organic Aerosols in Southern California during the 2005 Study of Organic Aerosols in Riverside (SOAR), Environ. Sci. Technol., 42, 7655-7662, doi:10.1021/es8008166, 2008.

Docherty, K. S., Aiken, A. C., Huffman, J. A., Ulbrich, I. M., DeCarlo, P. F., Sueper, D., Worsnop, D. R., Snyder, D. C., Grover, B. D., Eatough, D. J., Goldstein, A. H., Ziemann, P. J., and Jimenez, J. L.: The 2005 Study of Organic Aerosols at Riverside (SOAR-1): instrumental intercomparisons and fine particle composition, Atmos. Chem. Phys. Discuss., 11, 6301-6362, doi:10.5194/acpd-11-6301-2011, 2011.

Duplissy, J., DeCarlo, P. F., Dommen, J., Alfarra, M. R., Metzger, A., Barmpadimos, I., Prevot, A. S. H., Weingartner, E., Tritscher, T., Gysel, M., Aiken, A. C., Jimenez, J. L., Canagaratna, M. R., Worsnop, D. R., Collins, D. R., Tomlinson, J., and Baltensperger, U.: Relating hygroscopicity and composition of organic aerosol particulate matter, Atmos. Chem. Phys., 11, 1155-1165, doi:10.5194/acp-11-1155-2011, 2011.

Farmer, D. K., Kimmel, J. R., Phillips, G., Docherty, K. S., Worsnop, D. R., Sueper, D., Nemitz, E., and Jimenez, J. L.: Eddy-Covariance Measurements with High-Resolution Timeof-Flight Aerosol Mass Spectrometry: A New Approach to Chemically-Resolved Aerosol Fluxes, Atmos. Meas. Tech. 4, 1275-1289, doi:10.5194/amt-4-1275-2011, 2011.

Fisher, J. A., Jacob, D. J., Purdy, M. T., Kopacz, M., Le Sager, P., Carouge, C. C., Holmes, C. D., Yantosca, R. M., Batchelor, R. L., Strong, K., Diskin, G. S., Fuelberg, H. E., Holloway, J. S., Hyer, E. J., McMillan, W. W., Warner, J. Streets, D. G., Zhang, Q., Wang, Y., and Wu, S.: Source attribution and interannual variability of Arctic pollution in spring constrained by aircraft (ARCTAS, ARCPAC) and satellite (AIRS) observa- 
tions of carbon monoxide, Atmos. Chem. Phys., 10, 977-996, doi:10.5194/acp-10-977-2010, 2010.

Fisher, J. A., Jacob, D. J., Wang, Q., Bahreini, R., Carouge, C. C., Cubison, M. J., Dibb, J. E., Diehl, T., Jimenez, J. L., Leibensperger, E. J., Meinders, M. B. J., Pye, H. O. T., Quinn, P. K., Sharma, S., van Donkelaar, A., and Yantosca, R. M.: Sources, distribution, and acidity of sulfateammonium aerosol in the Arctic in winter-spring, Atmos. Environ., doi:10.1016/j.atmosenv.2011.08.030, 2011.

Fuelberg, H. E., Harrigan, D. L., and Sessions, W.: A meteorological overview of the ARCTAS 2008 mission, Atmos. Chem. Phys., 10, 817-842, doi:10.5194/acp-10-817-2010, 2010.

George, I. J., and Abbatt, J. P. D.: Heterogeneous oxidation of atmospheric aerosol particles by gas-phase radicals, Nature Chem., 2, 713-722, doi:10.1038/nchem.806, 2010.

Grieshop, A. P., Logue, J. M., Donahue, N. M., and Robinson, A. L.: Laboratory investigation of photochemical oxidation of organic aerosol from wood fires 1: measurement and simulation of organic aerosol evolution, Atmos. Chem. Phys., 9, 1263-1277, doi:10.5194/acp-9-1263-2009, 2009a.

Grieshop, A. P., Donahue, N. M., and Robinson, A. L.: Laboratory investigation of photochemical oxidation of organic aerosol from wood fires 2: analysis of aerosol mass spectrometer data, Atmos. Chem. Phys., 9, 2227-2240, doi:10.5194/acp-9-2227-2009, 2009b.

Hallquist, M., Wenger, J. C., Baltensperger, U., Rudich, Y., Simpson, D., Claeys, M., Dommen, J., Donahue, N. M., George, C., Goldstein, A. H., Hamilton, J. F., Herrmann, H., Hoffmann, T., Iinuma, Y., Jang, M., Jenkin, M. E., Jimenez, J. L., Kiendler-Scharr, A., Maenhaut, W., McFiggans, G., Mentel, Th. F., Monod, A., Prévôt, A. S. H., Seinfeld, J. H., Surratt, J. D., Szmigielski, R., and Wildt, J.: The formation, properties and impact of secondary organic aerosol: current and emerging issues, Atmos. Chem. Phys., 9, 5155-5236, doi:10.5194/acp-95155-2009, 2009.

Hansel, A., Jordan, A., Holzinger, R., Prazeller, P., Vogel, W., and Lindinger, W.: Proton-Transfer Reaction Mass-Spectrometry Online Trace Gas-Analysis at the ppb Level, Int. J. Mass Spectrom., 149, 609-619, 1995.

Hawkins, L. N. and Russell, L. M.: Oxidation of ketone groups in transported biomass burning aerosol from the 2008 Northern California Lightning Series fires, Atmos. Environ., 44, 41424154, doi:10.1016/j.atmosenv.2010.07.036, 2010.

Hecobian, A., Liu, Z., Hennigan, C. J., Huey, L. G., Jimenez, J. L., Cubison, M. J., Vay, S., Diskin, G. S., Sachse, G. W., Wisthaler, A., Mikoviny, T., Weinheimer, A. J., Liao, J., Knapp, D. J., Wennberg, P. O., Kürten, A., Crounse, J. D., Clair, J. St., Wang, Y., and Weber, R. J.: Comparison of the chemical evolution and characteristics of 495 biomass burning plumes intercepted by the NASA DC- 8 aircraft during the ARCTAS/CARB-2008 field campaign, Atmos. Chem. Phys. Discuss., 11, 18589-18631, doi:10.5194/acpd-11-18589-2011, 2011

Hennigan, C. J., Sullivan, A. P., Collett, J. L., and Robinson, A. L.: Levoglucosan stability in biomass burning particles exposed to hydroxyl radicals, Geophys. Res. Lett., 37, L09806, doi:10.1029/2010GL043088, 2010a.

Hennigan, C. J., Miracolo, M. A., Engelhart, G. J., May, A. A., Presto, A. A., Lee, T., Sullivan, A. P., McMeeking, G. R., Coe, H., Wold, C. E., Hao, W.-M., Gilman, J. B., Kuster, W. C., de
Gouw, J., Schichtel, B. A., J. L. Collett Jr., Kreidenweis, S. M., and Robinson, A. L.: Chemical and physical transformations of organic aerosol from the photo-oxidation of open biomass burning emissions in an environmental chamber, Atmos. Chem. Phys., 11, 7669-7686, doi:10.5194/acp-11-7669-2011, 2011.

Hoffmann, D., Tilgner, A., Iinuma, Y., and Herrmann, H.: Atmospheric Stability of Levoglucosan: A Detailed Laboratory and Modeling Study, Environ. Sci. Technol., 44, 694-699, 2010.

Hudman, R. C., Jacob, D. J., Turquety, S., Leibensperger, E. M., Murray, L. T., Wu, S., Gilliland, A. B., Avery, M., Bertram, T. H., and Brune, W.: Surface and lightning sources of nitrogen oxides over the United States: Magnitudes, chemical evolution, and outflow, J. Geophys. Res., 112, D12S05, doi:10.1029/2006JD007912, 2007.

Huffman, J. A., Docherty, K. S., Aiken, A. C., Cubison, M. J., U1brich, I. M., DeCarlo, P. F., Sueper, D., Jayne, J. T., Worsnop, D. R., Ziemann, P. J., and Jimenez, J. L.: Chemically-resolved aerosol volatility measurements from two megacity field studies, Atmos. Chem. Phys., 9, 7161-7182, doi:10.5194/acp-9-71612009, 2009a.

Huffman, J. A., Docherty, K. S., Mohr, C., Cubison, M. J., Ulbrich, I. M., Ziemann, P. J., Onasch, T. B., and Jimenez, J. L.: Chemically-Resolved Volatility Measurements of Organic Aerosol from Different Sources. Environ. Sci. Technol., 43, 5351-5357, doi:10.1021/es803539d, 2009b.

Hung, H. M. and Tang, C. W.: Effects of Temperature and Physical State on Heterogeneous Oxidation of Oleic Acid Droplets with Ozone, J. Phys. Chem., A114, 13104-13112, 2010.

Jacob, D. J., Crawford, J. H., Maring, H., Clarke, A. D., Dibb, J. E., Emmons, L. K., Ferrare, R. A., Hostetler, C. A., Russell, P. B., Singh, H. B., Thompson, A. M., Shaw, G. E., McCauley, E., Pederson, J. R., and Fisher, J. A.: The Arctic Research of the Composition of the Troposphere from Aircraft and Satellites (ARCTAS) mission: design, execution, and first results, Atmos. Chem. Phys., 10, 5191-5212, doi:10.5194/acp-10-5191-2010, 2010.

Jimenez, J. L., Jayne, J. T., Shi, Q., Kolb, C. E., Worsnop, D. R., Yourshaw, I., Seinfeld, J. H., Flagan, R. C., Zhang, X., Smith, K. A., Morris, J., and Davidovits, P.: Ambient Aerosol Sampling with an Aerosol Mass Spectrometer, J. Geophys. Res.-Atmos., 108, 8425, doi:10.1029/2001JD001213, 2003.

Jimenez, J. L., Canagaratna, M. R., Donahue, N. M., Prevot, A. S. H., Zhang, Q., Kroll, J. H., DeCarlo, P. F., Allan, J. D., Coe, H., Ng, N. L., Aiken, A. C., Docherty, K. D., Ulbrich, I.M., Grieshop, A. P., Robinson, A. L., Duplissy, J., Smith, J. D., Wilson, K. R., Lanz, V. A., Hueglin, C., Sun, Y. L., Tian, J., Laaksonen, A., Raatikainen, T., Rautiainen, J., Vaattovaara, P., Ehn, M., Kulmala, M., Tomlinson, J. M., Collins, D. R., Cubison, M. J., Dunlea, E. J., Huffman, J. A., Onasch, T. B., Alfarra, M. R., Williams, P. I., Bower, K., Kondo, Y., Schneider, J., Drewnick, F., Borrmann, S., Weimer, S., Demerjian, K., Salcedo, D., Cottrell, L., Griffin, R., Takami, A., Miyoshi, T., Hatakeyama, S., Shimono, A., Sun, J. Y., Zhang, Y. M., Dzepina, K., Kimmel, J. R., Sueper, D., Jayne, J. T., Herndon, S. C., Trimborn, A. M., Williams, L. R., Wood, E. C., Kolb, C. E., Middlebrook, A. M., Baltensperger, U., and Worsnop, D. R.: Evolution of Organic Aerosols in the Atmosphere, Science, 326, 1525-1529, doi:10.1126/science.1180353, 2009.

Kang, E., Root, M. J., Toohey, D. W., and Brune, W. H.: Introducing the concept of Potential Aerosol Mass (PAM), Atmos. Chem. 
Phys., 7, 5727-5744, doi:10.5194/acp-7-5727-2007, 2007.

Kang, E., Toohey, D. W., and Brune, W. H.: Dependence of SOA oxidation on organic aerosol mass concentration and $\mathrm{OH}$ exposure: experimental PAM chamber studies, Atmos. Chem. Phys., 11, 1837-1852, doi:10.5194/acp-11-1837-2011, 2011.

Katrib, Y., Biskos, G., Buseck, P. R., Davidovits, P., Jayne, J. T., Mochida, M., Wise, M. E., Worsnop, D. R., and Martin, S. T.: Ozonolysis of mixed oleic-acid/stearic-acid particles: Reaction kinetics and chemical morphology, J. Phys, Chem. A., 109, 10910-10919, doi:10.1021/jp054714d, 2005.

Kessler, S. H., Smith, J. D., Che, D. L., Worsnop, D. R., Wilson, K. R., and Kroll, J. H.: Chemical Sinks of Organic Aerosol: Kinetics and Products of the Heterogeneous Oxidation of Erythritol and Levoglucosan, Environ. Sci. Technol., 44, 7005-7010, doi:10.1021/es101465m, 2010.

Kimmel, J. R., Farmer, D. K., Cubison, M. J., Sueper, D., Tanner, C., Nemitz, E., Worsnop, D. R., Gonin, M., and Jimenez, J. L.: Real-time Aerosol Mass Spectrometry with Millisecond Resolution, Int. J. Mass. Spectrom., 303, 15-26, doi:10.1016/j.ijms.2010.12.004, 2011.

Kroll, J. H., Donahue, N. M. Jimenez, J. L., Kessler, S. H., Canagaratna, M. R., Wilson, K. R., Altieri, K. E., Mazzoleni, L. R., Wozniak, A. S., Bluhm, H., Mysak, E. R., Smith, J. D., Kolb, C. E., and Worsnop, D. R.: Carbon Oxidation State as a Metric for Describing the Chemistry of Atmospheric Organic Aerosol, Nature Chem., 3, 133-139, doi:10.1038/NCHEM.948, 2011.

Lee, T., Sullivan, A. P., Mack, L., Jimenez, J. L., Kreidenweis, S. M., Onasch, T. B., Worsnop, D. R., Malm, W., Wold, C. E., Hao, W. M., and Collett, J. L.: Variation of chemical smoke marker emissions during flaming vs. smoldering phases of laboratory open burning of wildland fuels, Aerosol Sci. Technol., 44, 1-5, doi:10.1080/02786826.2010.499884, 2010

Liggio J., Li S. M., and McLaren, R.: Reactive update of glyoxal by particulate matter, J. Geophys. Res., 110, D10304, doi:10.1029/2004JD005113, 2005.

Massoli, P., Lambe, A. T., Ahern, A. T., Williams, L. R., Ehn, M., Mikkilä, J., Canagaratna, M. R., Brune, W. H., Onasch, T. B., Jayne, J.T., Petäjä, T., Kulmala, M., Laaksonen, A., Kolb, C. E. Davidovits, P., and Worsnop, D. R.: Relationship between Aerosol Oxidation Level and Hygroscopic Properties of Laboratory Generated Secondary Organic Aerosol (SOA) Particles, Geophys. Res. Lett., 37, L24801, doi:10.1029/2010GL045258, 2010.

McMeeking, G. R., Kreidenweis, S. M., Baker, S., Carrico, C. M., Chow, J. C., Collett, J. L., Hao, W. M., Holden, A. S., Kirchstetter, T. W., Malm, W. C., Moosmuller, H., Sullivan, A. P., and Wold, C. E.: Emissions of trace gases and aerosols during the open combustion of biomass in the laboratory, J. Geophys. Res., 114, D19210, doi:10.1029/2009JD011836, 2009.

Mohr, C., Huffman, J. A., Cubison, M. J., Aiken, A. C., Docherty, K. S., Kimmel, J. R., Ulbrich, I. M., Hannigan, M., Garcia, J., and Jimenez, J. L.: Characterization of Primary Organic Aerosol Emissions from Meat Cooking, Trash Burning, and Motor Vehicles with High-Resolution Aerosol Mass Spectrometry and Comparison with Ambient and Chamber Observations, Environ. Sci. Technol., 43, 2443-2449, doi:10.1021/es8011518, 2009.

Murphy, D. M. Czizco, D. J., Froyd, K. D., Hudson, P. K., Matthew, B. M., Middlebrook, A. M., Peltier, R. E., Sullivan, A., Thomson, D. S., and Weber, R. J.: Single-particle mass-spectrometry of tropospheric aerosol particles, J. Geophys. Res., 111, D23S32, doi:10.1029/2006JD007340, 2006.

Ng, N. L., Canagaratna, M. R., Zhang, Q., Jimenez, J. L., Tian, J., Ulbrich, I. M., Kroll, J. H., Docherty, K. S., Chhabra, P. S., Bahreini, R., Murphy, S. M., Seinfeld, J. H., Hildebrandt, L., Donahue, N. M., DeCarlo, P. F., Lanz, V. A., Prévôt, A. S. H., Dinar, E., Rudich, Y., and Worsnop, D. R.: Organic aerosol components observed in Northern Hemispheric datasets from Aerosol Mass Spectrometry, Atmos. Chem. Phys., 10, 46254641, doi:10.5194/acp-10-4625-2010, 2010.

Ng, N. L., Herndon, S. C., Trimborn, A., Canagaratna, M. R., Croteau, P., Onasch, T. M., Sueper, D., and Worsnop, D. R.: An Aerosol Chemical Speciation Monitor (ACSM) for routine monitoring of atmospheric aerosol composition, Aerosol Sci. Technol., 45, 770-784, 2011a.

Ng, N. L., Canagaratna, M. R., Jimenez, J. L., Zhang, Q., Ulbrich, I. M., and Worsnop, D. R.: Real-Time Methods for Estimating Organic Component Mass Concentrations from Aerosol Mass Spectrometer Data, Environ. Sci. Technol., 45, 910-916, doi:10.1021/es102951k, 2011b.

Ortega, A., Brune, W., Cubison, M. J., Welsh-Bon, D., de Gouw, J. A., Lee, T., Kreidenweis, S., Robinson, A. L., Hennigan, C. J., and Jimenez, J. L.: Variability of Secondary Organic Aerosol Production and Aerosol Oxidation from Rapid and Intense Photochemical Processing of Biomass Burning Smokes, International Aerosol Conference, Helsinki, Finland, 29 August3 September 2010, P3W32, available online at: http://www.atm. helsinki.fi/IAC2010/abstracts/pdf/224.pdf, 2010.

Robinson, A. L., Subramanian, R., Donahue, N. M., BernardoBricke, A., and Rogge, W. F.: Source Apportionment of Molecular Markers and Organic Aerosol1. Polycyclic Aromatic Hydrocarbons and Methodology for Data Visualization, Environ. Sci. Technol., 40, 7803-7810, doi:10.1021/es0510414, 2006.

Robinson, A. L., Donahue, N. M., Shrivastava, M. K., Weitkamp, E. A., Sage, A. M., Grieshop, A. P., Lane, T. E., Pierce, J. R., and Pandis, S. N.: Rethinking organic aerosols: Semivolatile emissions and photochemical aging, Science, 315, 1259-1262, doi:10.1126/science.1133061, 2007.

Sachse, G. W., Hill, G. F., and Perry, M. G.: Fast-response, highprecision Carbon Monoxide sensor using a tunable diode-laser absorption technique, J. Geophys. Res., 92, 2071-2081, 1987.

Sage, A. M., Weitkamp, E. A., Robinson, A. L., and Donahue, N. M.: Evolving mass spectra of the oxidized component of organic aerosol: results from aerosol mass spectrometer analyses of aged diesel emissions, Atmos. Chem. Phys., 8, 1139-1152, doi:10.5194/acp-8-1139-2008, 2008.

Schauer, J. J., Rogge, W. F. Hildemann, L. M., Mazurek, M. A., and Cass, G. R.: Source apportionment of airborne particulate matter using organic compounds as tracers, Atmos. Environ., 30, 3837-3855, 1996.

Schneider, J., Weimer, S., Drewnick, F., Borrmann, S., Helas, G., Gwaze, P., Schmid, O., Andreae, M. O. and Kirchner, U.: Mass spectrometric analysis and aerodynamic properties of various types of combustion-related aerosol particles, Int. J. Mass. Spec., 258, 37-49, 2006.

Simoneit, B. R. T., Schauer, J. J., Nolte, C. G., Oros, D. R., Elias, V. O., Fraser, M. P., Rogge, W. F., Cass, G. R.: Levoglucosan, a tracer for cellulose in biomass burning and atmospheric particles, Atmos. Environ., 33, 173-182, 1999. 
Singh, H. B., Anderson, B. E., Brune, W. H., Cai, C., Cohen, R. C., Crawford, J. H., Cubison, M. J., Czech, E. P., Emmons, L., Fuelberg, H. E., Huey, G., Jacob, D. J., Jimenez, J. L., Kaduwela, A., Kondo, Y., Mao, J., Olson, J. R., Sachse, G. W., Vay, S. A., Weinheimer, A., Wennberg, P. O., Wisthaler, A., and the ARCTAS Science Team: Pollution influences on atmospheric composition and chemistry at high northern latitudes: Boreal and California forest fire emissions, Atmos. Environ., 44, 4553-4564, doi:10.1016/j.atmosenv.2010.08.026, 2010.

Skamarock, W. C., Klemp, J. B., Dudhia, J., Gill, D. O. Baker, D. M., Duda, M. G., Huang, X., Wang, W., and Powers, J. G.: A description of the Advanced Research WRF version 3.874, NCAR Tech. Note NCAR/TN-475+STR, 113, 2008.

Spracklen, D. V., Jimenez, J. L., Carslaw, K. S., Worsnop, D. R., Evans, M. J., Mann, G. W., Zhang, Q., Canagaratna, M. R., Allan, J., Coe, H., McFiggans, G., Rap, A., and Forster, P.: Aerosol mass spectrometer constraint on the global secondary organic aerosol budget, Atmos. Chem. Phys. Discuss., 11, 5699-5755, doi:10.5194/acpd-11-5699-2011, 2011.

Takegawa, N., Miyakawa, T., Kawamura, K., and Kondo, Y.: Contribution of Selected Dicarboxylic and w-Oxocarboxylic Acids in Ambient Aerosol to the $\mathrm{m} / \mathrm{z} 44$ Signal of an Aerodyne Aerosol Mass Spectrometer, Aerosol Sci. Technol., 41, 418-437, 2007.

Ulbrich, I. M., Canagaratna, M. R., Zhang, Q., Worsnop, D. R., and Jimenez, J. L.: Interpretation of organic components from Positive Matrix Factorization of aerosol mass spectrometric data, Atmos. Chem. Phys., 9, 2891-2918, doi:10.5194/acp-9-2891-2009, 2009a.

Ulbrich, I. M., Lechner, M., and Jimenez, J. L.: AMS Spectral Database, http://cires.colorado.edu/jimenez-group/AMSsd/, last access: 2 December 2011, 2009b.

Vaden, T. D., Imre, D., Beranek, J., Shrivastava, M., and Zelenyuk, A.: Evaporation kinetics and phase of laboratory and ambient secondary organic aerosol, PNAS, 108, 2190-2195, doi:10.1073/pnas.1013391108, 2011.

Virtanen, A., Joutsensaara, J., Koop, T., Kannosto, J., Yli-Pirila, P., Leskinen, J., Makela, J. M., Holopainen, J. K., Pöschl, U., Kulmala, M., Worsnop, D. R., and Laaksonen, A.: An amorphous solid state of biogenic secondary organic aerosol particles, Nature, 467, 824-827, doi:10.1038/nature09455, 2010.

Volkamer, R., Jimenez, J. L., San Martini, F., Dzepina, K., Zhang, Q., Salcedo, D., Molina, M. T., Worsnop, D. R., and Molina, M. J.: Secondary organic aerosol formation from anthropogenic air pollution: Rapid and higher than expected, Geophys. Res. Lett., 33, L17811, doi:10.1029/2006GL026899, 2006.

Wang, Q., Jacob, D. J., Fisher, J. A., Mao, J., Leibensperger, E. M., Carouge, C. C., Le Sager, P., Kondo, Y., Jimenez, J. L., Cubison, M. J., and Doherty, S. J.: Sources of carbonaceous aerosols and deposited black carbon in the Arctic in winter-spring: implications for radiative forcing, Atmos. Chem. Phys. Discuss., 11, 19395-19442, doi:10.5194/acpd-11-19395-2011, 2011.

Warneke, C., Bahreini, R., Brioude, J., Brock, C. A., de Gouw, J. A., Fahey, D. W., Froyd, K. D., Holloway, J. S., Middlebrook, A. M., Miller, L., Montzka, S., Murphy, D. M., Peischl, J., Ryerson, T. B., Schwarz, J. P., Spackmann, J. R., and Veres, P.: Biomass burning in Siberia and Kazakhstan as an important source for haze over the Alaskan Arctic in April 2008, Geophys. Res. Lett., 36, L02813, doi:10.1029/2008GL036194, 2009.
Warneke, C., Froyd, K. D., Brioude, J., Bahreini, R., Brock, C. A., Cozic, J., de Gouw, J. A., Fahey, D. W., Ferrare, R., Holloway, J. S., Middlebrook, A. M., Miller, L., Montzka, S., Schwarz, J. P., Sodemann, H., Spackmann, J. R., and Stohl, A.: An important contribution to springtime Arctic aerosol from biomass burning in Russia, Geophys. Res. Lett., 37, L01801, doi:10.1029/2009GL041816, 2010.

Weimer, S., Alfarra, M. R., Schreiber, D., Mohr, C., Prevot, A. S. H., and Baltensperger, U.: Organic aerosol mass spectral signatures from wood-burning emissions: Influence of burning conditions and wood type, J. Geophys. Res., 113, D10304, doi:10.1029/2007JD009309, 2008.

Weinheimer, A. J., Walega, J. G., Ridley, B. A., Gary, B. L., Blake, D. R., Blake, N. J., Rowland, F. S., Sachse, G. W., Anderson, B. E., and Collins, J. E.: Meridional distributions of $\mathrm{NO}_{\mathrm{x}}, \mathrm{No}_{\mathrm{y}}$, and other species in the lower stratosphere and upper troposphere during AASE II, Geophys. Res. Lett., 21, 2583-2586, 1994.

Wisthaler, A., Hansel., A., Dickerson, R. R., and Crutzen, P. J.: Organic trace gas measurements by PTR-MS during INDOEX 1999, J. Geophys. Res. 107, D8024, doi:10.1029/2001JD000576, 2002.

Wisthaler, A., Mikoviny, T., Diskin, G. S., Sachse, G. W., and Burkhart, J. F.: Chemical characterization of air masses transported to the Arctic during the ARCTAS-A spring deployment: biomass burning versus fossil fuel combustion signatures, AGU Fall Meeting, San Francisco, USA, A33F-05, 2009.

Yokelson, R. J., Crounse, J. D., DeCarlo, P. F., Karl, T., Urbanski, S., Atlas, E., Campos, T., Shinozuka, Y., Kapustin, V., Clarke, A. D., Weinheimer, A., Knapp, D. J., Montzka, D. D., Holloway, J., Weibring, P., Flocke, F., Zheng, W., Toohey, D., Wennberg, P. O., Wiedinmyer, C., Mauldin, L., Fried, A., Richter, D., Walega, J., Jimenez, J. L., Adachi, K., Buseck, P. R., Hall, S. R., and Shetter, R.: Emissions from biomass burning in the Yucatan, Atmos. Chem. Phys., 9, 5785-5812, doi:10.5194/acp-9-5785-2009, 2009.

Zhang, Q., Jimenez, J. L., Canagaratna, M. R., Allan, J. D., Coe, H., Ulbrich, I., Alfarra, M. R., Takami, A., Middlebrook, A. M., Sun, Y. L., Dzepina, K., Dunlea, E., Docherty, K. S., DeCarlo, P. F., Salcedo, D., Onasch, T., Jayne, J. T., Miyoshi, T., Shimono, A., Hatakeyama, S., Takegawa, N., Kondo, Y., Schneider, J., Drewnick, F., Weimer, S., Demerjian, K., Williams, P. I., Bower, K., Bahreini, R., Cottrell, L., Griffin, R. J., Rautiainen, J., and Worsnop, D. R.: Ubiquity and Dominance of Oxygenated Species in Organic Aerosols in Anthropogenically - Influenced Northern Hemisphere Mid-latitudes. Geophys. Res. Lett., 34, L13801, doi:10.1029/2007GL029979, 2007.

Zhang, X., Hecobian, A., Zheng, M., Frank, N. H., and Weber, R. J.: Biomass burning impact on $\mathrm{PM}_{2.5}$ over the southeastern US during 2007: integrating chemically speciated FRM filter measurements, MODIS fire counts and PMF analysis, Atmos. Chem. Phys., 10, 6839-6853, doi:10.5194/acp-10-6839-2010, 2010.

Ziemann, P. J.: Aerosol products, mechanisms, and kinetics of heterogeneous reactions of ozone with oleic acid in pure and mixed particles, Faraday Discuss., 130, 469-490, doi:10.1039/b417502f, 2005. 